\title{
O PROJETO NA PóS-GRADUAÇÃO STRICTO SENSU: A PRÁTICA PROJETUAL NOS ATELIÊS DO MESTRADO PROFISSIONAL EM ARQUTTETURA DA UFRN
}

\section{VELOSO, MAÍSA}

Arquiteta, Doutora,PPGAU/UFRN, e-mail: maisaveloso@gmail.com

\section{ELALI, GLEICE AZAMBUJA}

Arquiteta, Psicóloga, Doutora, PPGAU/UFRN, e-mail: gleiceae@gmail.com

\section{INTRODUÇÃO}

Nesta seção, fazemos uma reflexão sobre o projetar no âmbito da pós-graduação stricto sensu, a partir da experiência vivenciada em seis anos de existência do Mestrado Profissional em Arquitetura, Projeto e Meio Ambiente, da Universidade Federal do Rio Grande do Norte (UFRN), pioneiro no Brasil na área de Arquitetura e Urbanismo (AU). Inicialmente comentamos os princípios da proposta pedagógica do curso, que foi estruturado em torno de três ateliês de projeto, e o percurso metodológico através deles, o que pudemos acompanhar de perto como professoras de projeto. Ao final da seção, são apresentadas seis dissertações de mestrado resultantes desta experiência, que correspondem a projetos de arquitetura desenvolvidos pelos mestrandos.

\section{MESTRADO PROFISSIONAL EM ARQUITETURA, PROJETO E MEIO AMBIENTE (MP-APMA)}

O MP-APMA teve início em agosto de 2010, sendo o primeiro mestrado profissional brasileiro da área de AU. Constitui uma expansão do Programa de Pós-graduação em Arquitetura e Urbanismo (PPGAU) da UFRN, que já possuía mestrado acadêmico (desde 1999) e doutorado (desde 2007). Aprovado pela CAPES em 2009, a nova proposta de mestrado profissional representou um grande desafio para a equipe envolvida, devido ao seu ineditismo nos estudos de pós-graduação stricto sensu em AU, notadamente por sua ênfase ao projeto de arquitetura e suas relações com o ambiente.

De acordo com o projeto de criação do curso (PPGAU/ UFRN, 2009), entre os seus principais

objetivos encontram-se:

a) Capacitar profissionais (projetistas, consultores e analistas de projetos de edificações), com nível superior completo na área de Arquitetura e Urbanismo e de
Engenharia Civil (isto é, profissionais capacitados a projetar ou a vistoriar edificações conforme atribuições do MEC e do Sistema CONFEA/CREA, e mais recentemente do $(A \cup)$, com perfil predominantemente técnico/não acadêmico, e com atuação em escritórios, empresas e órgãos públicos ou privados no âmbito local, regional e nacional, para o exercício de suas funções em bases teóricas e metodológicas mais consistentes, a partir da prática da pesquisa científica relacionada às linhas de investigação e aos eixos temáticos priorizados no curso, quais sejam: projeto, morfologia e usos da arquitetura, sustentabilidade, conforto ambiental, eficiência energética, acessibilidade e segurança das edificações.

b) Relacionar as práticas profissionais atualmente desenvolvidas no meio não acadêmico com os enfoques teórico-metodológicos privilegiados nas pesquisas e estudos da área de concentração de Projeto, Morfologia e Conforto no Ambiente Construído e a eles adequálas com base nos suportes conceituais e instrumentais oferecidos, ampliando seus universos de abrangência de problemáticas locais ou regionais para nacionais e internacionais, a partir de análises críticas comparadas.

c) Difundir os conhecimentos (o capital intelectual) acumulados no Programa de Pós-graduação em Arquitetura e Urbanismo da UFRN, expandindo este potencial para além das esferas acadêmicas locais e regionais, e contribuindo, assim, para o desenvolvimento de questões relativas ao projeto de arquitetura e sua adequação ao meio físico e sociocultural em que está inserido.

Em suma, o principal objetivo do MP-APMA é pensar e produzir arquitetura de qualidade, estreitando as relações entre projeto e meio ambiente, por meio do desenvolvimento de propostas que integrem fazeres e saberes profissionais e acadêmicos. 


\section{A PROPOSTA PEDAGÓGICA DO MESTRADO PROFISSIONAL}

Com uma área de concentração e três linhas de pesquisa (Projeto de Arquitetura; Morfologia e Usos da Arquitetura; Conforto Ambiental e Eficiência Energética), a proposta pedagógica do MP-APMA está fundamentada em princípios e premissas compartilhados pelos docentes que 0 conceberam e transmitidos aos discentes desde nossos primeiros contatos:

1- O ato de projetar edifícios, além de atividade técnica e/ ou artística, é também passível de reflexão teórica e de procedimentos metodológicos sistematizados;

2- O projeto, documento que entendemos consubstanciar o pensamento arquitetural de uma época, constitui importante fonte de conhecimentos e pode ser objeto de pesquisas científicas;

3- A reflexão sobre o projeto deve ser compreendida como área prioritária nos estudos estratégicos da cidade e da ocupação do território, pois parte considerável do ambiente construído é resultado de projetos; nesse sentido, torna-se indispensável a consideração das questões ambientais e dos usuários dos espaços projetados.

4- Pedagogicamente, os princípios que fundamentam o ato de projetar no âmbito dos ateliês do MP-APMA são: a reflexão na ação, a interdisciplinaridade e a interação de conteúdos que dão suporte teórico-metodológico e instrumental ao projeto.

Para atender a esses pré-requisitos, todas as disciplinas oferecidas no curso relacionamse entre si e convergem para a aplicação de seus conteúdos no projeto desenvolvido individualmente pelo aluno no Atelier Integrado. $O$ ateliê de projeto torna-se, portanto, não apenas lócus de convergência dos conhecimentos adquiridos, mas, também, de confronto com as práticas profissionais dos discentes e, à maneira de Donald Schön (2000), da discussão coletiva baseada no princípio da "reflexão na ação". Ressalte-se que o curso não visa ensinar - aluno a projetar (uma vez que esta é uma função da graduação), e sim respaldar e otimizar o processo de projetação, incutindo em suas práticas profissionais a pesquisa científica, novos instrumentais analíticos e de suporte à concepção projetual e, sobretudo, a reflexão teórico-metodológica.
Em 2011, no V Seminário PROJETAR, realizado em Belo Horizonte, apresentamos uma reflexão inicial sobre os dois primeiros anos de experiência do nosso Mestrado Profissional (VELOSO; ELALI, 2011). O artigo intitulado Ensinado (novas) rezas a (velhos) vigários..., focava sobretudo a questão da integração dos saberes e fazeres nos ateliês de projeto do curso, com base na prática vivenciada e em produtos parciais da primeira turma. Cinco anos e três turmas depois, com 37 projetos/ dissertações já defendidos, temos hoje mais insumos para revisitar aquela discussão, focando agora no percurso metodológico dos ateliês e nos produtos por eles gerados.

\section{OS ATELIÊS DE PROJETO DO MESTRADO PROFISSIONAL}

Entendendo-se o projeto como a hipótese defendida pelo projetista diante de uma questão problema enfrentada, o produto esperado para o mestrado profissional é uma proposta de arquitetura (nível de estudo preliminar, anteprojeto ou projeto executivo, dependendo do objetivo de cada um e da complexidade do objeto trabalhado), acompanhado por uma dissertação que problematiza a questão em estudo e explana detalhadamente o processo projetual e a solução adotada, bem como seus fundamentos teóricos e metodológicos.

Neste cenário, os ateliês de projeto constituem uma espécie de 'espinha dorsal' do mestrado, à qual se vinculam as demais disciplinas obrigatórias ou optativas cursadas pelos estudantes à medida que suas propostas evoluem. O processo de projeto tem início no Atelier Integrado I (primeiro semestre), e continua durante os Ateliers Integrados II e II, que acontecem, respectivamente, no segundo e terceiro semestres. Nos diferentes ateliês, a atuação do orientador individual soma-se à atividade dos professores responsáveis por estas disciplinas, voltando-se para práticas reflexivas e aplicação de conteúdos adquiridos durante o curso (conhecimentos específicos e ferramentas analíticas ou projetuais discutidas nas demais disciplinas obrigatórias ou optativas). Uma das tônicas dos diversos ateliers é a discussão coletiva, notadamente as sessões de apresentação de trabalhos, das quais participam todos os docentes e discentes do curso, e que se configuram como ricos momentos de crítica construtiva. 
No Atelier I é formulado o plano de trabalho individual para desenvolvimento do Trabalho de Conclusão do Curso. Nele acontece a definição do tema, objeto, objetivos e procedimentos básicos para a elaboração do projeto arquitetônico, segundo um ou mais dos seguintes enfoques do mestrado, como sejam, sustentabilidade, conforto ambiental, eficiência energética, acessibilidade e segurança dos edifícios. Durante o semestre são realizados exercícios gerais de concepção projetual e estudos de referência (análise de outros projetos que possam alimentar a proposta em andamento).

No Atelier II acontece a concepção das ideias iniciais e o desenvolvimento dos estudos preliminares para edificações ou pequenos conjuntos edificados, com base em procedimentos metodológicos apropriados a cada temática. O objetivo deste atelier é, gradativamente, conduzir os mestrandos a uma resposta inicial ao problema de projeto e aos objetivos fixados nos planos de trabalho individuais. Durante o semestre são trabalhados o conceito, o partido, a programação arquitetônica e feita a concepção inicial do estudo preliminar. Entendendo-se a importância da programação arquitetônica como um dos alicerces da proposta projetual, detalhando seus componentes e metas, uma das práticas nesse campo tem sido a realização de um workshop com a participação da profa. Dra. Doris Kowaltowski (Unicamp). Outros professores e profissionais externos ao Programa também são convidados a dar palestras ou minicursos. Com os estudos preliminares e o Atelier II concluídos, ocorrem os exames de qualificação.
No Atelier III são orientados os passos finais do Trabalho de Conclusão de Curso, geralmente envolvendo elementos a serem posteriormente detalhados ou comprovados por meio de simulações computacionais. Nesse momento, a proposta do mestrando está em fase final, sendo dedicada especial atenção à sua apresentação gráfica, ao memorial descritivo do processo e à justificativa das soluções projetuais empregadas, em atendimento aos objetivos previamente fixados. A defesa do projeto/dissertação é realizada a partir da aprovação do trabalho no Seminário final do Atelier III (do qual a participam todos os professores orientadores), ou seja, ao final dos 18 meses regulares do curso, podendo se estender, no máximo, até 24 meses. Das bancas de defesa pública, participam três examinadores, todos doutores, sendo pelo menos um externo à instituição. É possível a participação de outro membro externo, não doutor, mas com notória atuação profissional no campo do projeto proposto pelo discente.

\section{PRINCIPAIS RESULTADOS}

Até agosto de 2016, trinta e sete projetos de conclusão de curso foram defendidos no Mestrado Profissional em Arquitetura, Projeto e Meio Ambiente da Universidade Federal do Rio Grande do Norte (Quadro 1), em suas turmas concluintes de 2012, 2014 e 2016 (inicialmente com entradas bienais, a partir de 2015, o curso passou a ter entrada anual). Estas dissertações voltaram-se principalmente para temas relacionados à habitação (12 dos 37 TCCs, ou seja, 30\%), seguida por educação (7) e saúde (5).

Quadro 1. Dissertações defendidas no Mestrado Profissional, por turma e por tema

\begin{tabular}{|l|c|c|c|c|}
\hline Tipo de projeto & T1 (2012) & T2 (2014) & T3 (2016) & TOTAL \\
\hline Habitação (HIS) & 3 (2) & 2 & $7(3)$ & $\mathbf{1 2 ~ ( 5 ) ~}$ \\
\hline Educação & 2 & 4 & 1 & $\mathbf{7}$ \\
\hline Saúde & 3 & 1 & 1 & $\mathbf{5}$ \\
\hline Empresarial/Institucional & - & 3 & 1 & $\mathbf{4}$ \\
\hline Cultural/Comunitário & 1 & 1 & 2 & $\mathbf{4}$ \\
\hline Patrimônio & 1 & 2 & - & $\mathbf{3}$ \\
\hline Uso Misto TOTAL & $\mathbf{1 0}$ & $\mathbf{1 4}$ & $\mathbf{1 3}$ & $\mathbf{3 7}$ \\
\hline
\end{tabular}

Fonte: Dados extraídos do site do programa (https://sigaa.ufrn.br/sigaa/public/ programa/portal.jsf?id=6967), trabalhado pelas autoras 
Como consequência da proposta do programa de mestrado, a grande tônica dos projetos tem sido a sustentabilidade ambiental, envolvendo otimização das condições de conforto ambiental em função do reconhecimento e respeito ao clima e demais características físico-ambientais da área de intervenção, busca por soluções arquitetônicas condizentes com a realidade/contexto cultural investigados, reaproveitamento de água e eficiência energética (inclusive etiquetagem) das edificações. Outras ferramentas importantes utilizadas em algumas proposições dos mestrandos foram a gramática da forma e a sintaxe espacial como auxílio à definição da forma dos edifícios, sempre articuladas às simulações de conforto e/ou eficiência energética. Ilustrando essa produção qualificada, exibimos a seguir seis das propostas defendidas no mestrado profissional da UFRN, aqui apresentadas pelos seus próprios autores:

André Felipe Alves - Todo brasileiro merece nível "A": habitação multifamiliar para o programa Minha Casa Minha Vida energeticamente eficiente (2012)

Verner Monteiro - Proposta de habitação de interesse social com ênfase no conforto térmico para a Zona Bioclimática-8

Petterson Dantas - Processo de concepção do projeto arquitetônico para uma escola de turismo

Mariana Gurgel Caldas - Condomínio de casas em Natal-RN: Um exemplo de síntese projetual utilizando princípios da Gramática da Forma
César Ciríaco - Um lugar onde os espaços ensinam: anteprojeto arquitetônico de uma escola infantil e fundamental I em Parnamirim/RN

Francisco Rocha Neto - Cais da Memória: um espaço de vivências afetivas com a cidade de Natal

\section{CONSIDERAÇÕES FINAIS}

Avaliações que são regularmente realizadas ao longo e também ao término do percurso das turmas do mestrado profissional em Arquitetura, Projeto e Meio Ambiente mostraram que, para os discentes, as contribuições mais importantes do curso dizem respeito à tomada de consciência do processo de projeto e à incorporação de novas maneiras de projetar ao seu cotidiano profissional, seguidos pela reflexão teórica sobre o problema-tema de projeto. Por sua vez, os docentes apontaram como maiores ganhos o contato aproximado com profissionais atuantes no mercado local/regional e a crítica construtiva às práticas acadêmicas, que poderão evoluir a partir deste debate conjunto. Na última avaliação trienal realizada pela CAPES (em 2013), o esforço da equipe da UFRN foi reconhecido, sendo a nota do curso elevada para 4. Esse quadro geral indica que a inserção do projeto na pós-graduação stricto sensu em Arquitetura da UFRN é uma experiência até aqui bem-sucedida, servindo de exemplo para outras iniciativas nesse campo, as quais devem ser apresentadas nas próximas edições da Revista PROJETAR.

\section{REFERÊNCIAS}

PROGRAMA DE PÓS-GRADUAÇÃO EM ARQUITETURA E URBANISMO DA UNIVERSIDADE FEDERAL DO RIO GRANDE DO NORTE (PPGAU/ UFRN). Projeto do curso do Mestrado Profissional em Arquitetura, Projeto e Meio Ambiente. Natal, RN. 2009.

SCHÖN, Donald. Educando o profissional reflexivo: um novo design para o ensino e a aprendizagem. Trad. Roberto Cataldo Costa. Porto Alegre: Artmed, 2000.

VELOSO, Maísa; ELALI, Gleice Azambuja. Ensinando (novas) rezas a (velhos) vigários: a integração de saberes e fazeres no atelier de projeto do mestrado profissional. V PROJETAR - 2011. Anais... Belo Horizonte, FAU/UFMG, 2011.

NOTA DO EDITOR (*) O conteúdo do artigo e as imagens nele publicadas são de responsabilidade do(s) autor(es). 


\author{
ALVES, ANDRÉ FELIPE MOURA \\ ALVES, André Felipe Moura \\ Arquiteto, MsC., Professor UNI-RN e diretor GA Arquitetura; Email: andre@ga.arq.br \\ Dissertação desenvolvida no Mestrado Profissional em Arquitetura, Projeto e Meio Ambiente da UFRN \\ Orientador: Aldomar Pedrini; Co-orientador: Carlos Nome
}

\title{
RESUMO EXPANDIDO
}

O programa "Minha Casa Minha Vida" (MCMV) foi criado para atender às demandas de habitação da população de baixa renda nas áreas urbanas e proporcionar o acesso à moradia com desempenho técnico, segurança e inclusão social (Ministério das Cidades, 2010). Contudo, o programa tem sido passível de muitas críticas, como a precariedade da tecnologia de construção e as condicionantes projetuais.

Para incentivar a otimização do desempenho térmico das habitações, foi criado o Programa Nacional de Etiquetagem de Edificações. Trata-se de uma resposta nacional às tendências mundiais de redução do impacto ambiental das construções e da crise nacional de abastecimento de energia elétrica ocorridas em 2001. A Etiqueta Nacional de Conservação de Energia (ENCE), proveniente deste Programa da Eletrobrás e Inmetro é preconizada pelo Regulamento Técnico da Qualidade para o nível de eficiência energética em edificações residenciais (RTQ-R).

Este texto relata, resumidamente, o percurso teórico, metodológico e programático de uma proposta de uma edificação residencial multifamiliar localizada na área de expansão urbana de Parnamirim/RN, inserida no Programa MCMV e com nível de eficiência energética máxima, conforme o RTQ-R. O objetivo principal da pesquisa foi então desenvolver o projeto arquitetônico de uma edificação residencial multifamiliar inserida no programa MCMV, com desempenho compatível com o nível "A" do RTQ-R, e que fosse, ao mesmo tempo, viável economicamente e sensível às questões ambientais. A escolha do tema foi motivada pela necessidade de melhoria da qualidade do projeto arquitetônico, face às restrições do programa governamental. Os objetivos específicos foram a proposta de uma agenda verde para uma construção residencial com redução do impacto ambiental e uma tabela de diretrizes para projeto energeticamente eficiente.

Para o desenvolvimento da pesquisa e do projeto dela decorrente, foram feitos estudos de referenciais teóricos e empíricos, programação arquitetônica, análise da programação, estudos de precedentes arquitetônicos e as consultas complementares, conforme Figura 1.

A revisão da literatura pertinente ao tema e o referencial teórico abordaram a habitação de interesse social no Brasil, o programa MCMV, o desenvolvimento sustentável, o desempenho ambiental e o RTQ-R. Na programação arquitetônica, etapa que precede ao projeto arquitetônico e na qual são feitos o planejamento e a organização de todas as informações que subsidiam o projeto, a metodologia adotada foi o Problem Seeking, de Peña e Parshall (2001). O estudo de precedentes arquitetônicos destacou características de projetos e edificações com potencial de real contribuição para o desenvolvimento da proposta arquitetônica. Os estudos de proposições oferecem a oportunidade de discutir as primeiras tentativas de solução do problema apresentado na programação, com a participação de orientadores e diversos colaboradores, para se chegar a uma solução do problema, adoção de um partido e sua evolução.

Para redução do impacto ambiental da proposta arquitetônica, justificando um desempenho ambiental favorável à sustentabilidade, foi elaborada uma agenda verde, a partir da revisão de fundamentos para projetos de edificações sustentáveis (KEELER, 2010) e o Selo Casa Azul da CEF (2010). Esta agenda abordou quatro áreas: uso racional de água, energia, material e manutenção do ar. No sentido de conduzir à edificação ao nível de eficiência "A", dada revisão do RTQ-R (método prescritivo), foi possível listar quais diretrizes poderiam ser 
adotadas no projeto arquitetônico, inclusive nesta proposta, para se obter um resultado satisfatório quanto à envoltória, item responsável por 2/3 do nível aferido pelo Regulamento para Zona Bioclimática 08 (área de intervenção no município de Parnamirim/RN).

As diretrizes de projeto são:

- mínimo de paredes internas;

- material com alto fator de calor solar e pouca espessura;

- ambiente com maior volume possível;

- ambiente com maior área possível;

- coberta e parede mais clara e reflexiva possível;

- máximo de dispositivos para sombreamento;

- priorizar ambientes sobre pilotis ou solo;

- material com capacidade térmica entre 50 e $250 \mathrm{kj} / \mathrm{m}^{2} f ;$

- $\quad$ abertura para ventilação com dimensão mais próxima possível da dimensão do vão da mesma abertura;

- e hierarquia para orientação de:

- $\quad$ paredes externas: sul - leste - norte - oeste;

- sombreamento: oeste - leste - norte - sul;

- aberturas: sul - norte - leste - oeste.

Os projetos escolhidos como referências para análise apresentam elementos ou características que se destacam pela sustentabilidade, tecnologia ou uso relacionado ao tema habitação de interesse social. Utilizando como referência a agenda verde proposta no referencial teórico e acrescentado as características positivas quanto à tecnologia da edificação e HIS de cada precedente estudado, foi elaborada tabela avaliativa e comparativa dos precedentes arquitetônicos. Com o referencial teórico, a programação arquitetônica e os estudos de precedentes realizados, iniciou-se a proposta arquitetônica, principal objetivo da pesquisa.

O partido adotado considerou proposições que atendessem às referências e ao contexto da proposta. Foram elaborados diagramas para auxiliar a leitura dos fatos e necessidades da programação para o terreno e contexto da proposta: fatos bioclimáticos, necessidades socioespaciais, visuais, fatos legais e fatos físicos. Os estudos preliminares foram influenciados pela redução à exposição ao Sol, estratégias volumétricas que amenizem as trocas de calor, exploração do potencial de ventilação e unidades habitacionais com aberturas orientadas para Norte e Sul. Após a concepção de cinco diferentes implantações, definiu-se a solução de uma edificação localizada na diagonal sudoeste-nordeste do terreno de 100,00×100,00m, com horizontalidade perpendicular ao sudeste (sentido médio da incidência dos ventos predominantes) e aberturas das unidades voltadas para Sul e Norte (Figura 2). Desta forma, o controle de insolação das aberturas se torna mais simplificado e preserva a vista dos usuários. A edificação tem oito pavimentos devido à limitação de gabarito, é composta por dois blocos aglutinados numa única edificação horizontal e por 21 unidades habitacionais por pavimento. A circulação horizontal é central, ligando as unidades norte e sul, e há três volumes para circulação vertical em atendimento à legislação vigente municipal e de Bombeiros.

As unidades estão dispostas de forma modular e a relação de cheios e vazios proporciona a permeabilidade ao vento e garante diferença de pressão nas aberturas das unidades (Figura 3).

A proposta é resultado da combinação dos elementos da programação arquitetônica: ventilação natural, geometria solar, relações socioespaciais, modulação construtiva, expansibilidade e flexibilidade espacial, compatibilização ao sistema construtivo e aos sistemas prediais, viabilidade econômica e redução do impacto ambiental. Após a definição do partido com os rebatimentos do programa desenvolvimento do projeto resultou na elaboração de maquete física do estudo preliminar (Figura 4); simulação computacional da ventilação a partir de CFD no software DesignBuilder (Figura 5) confirmando o escoamento dos ventos; modelagem da edificação em plataforma BIM (Building Information Model); representação gráfica no formato de anteprojeto arquitetônico e avaliação do nível de eficiência energética conforme RTQ-R. 
Após a conferência da envoltória, sistema de aquecimento de água e bonificações de cada unidade habitacional, obteve-se a pontuação da edificação multifamiliar a partir da média ponderada dos níveis de eficiência energética de todos apartamentos por suas áreas úteis. O cálculo desta média ponderada foi 4,50, portanto nível "A" de eficiência energética para edificação proposta.

O produto arquitetônico contemplou então os aspectos revisados e programados na pesquisa, tendo sido concebida uma edificação multifamiliar com impacto ambiental reduzido. Foi comprovado ser uma edificação viável economicamente, mas com qualidade socioespacial e conforto térmico. A hipótese de que "todo brasileiro merece nível 'A"' como uma metáfora de que é possível produzir uma moradia energeticamente eficiente diante das restrições do programa governamental e viabilidade econômica foi confirmada. É possível reduzir o déficit habitacional proporcionando conforto ambiental e espacial, custos compatíveis da aquisição e manutenção, infraestrutura de lazer e de serviços urbanos, redução de impacto ambiental e do entorno. Para isto, é necessário buscar alternativas formais e conciliar informações de diferentes disciplinas para uma proposta arquitetônica coerente com a demanda. Nas figuras abaixo algumas perspectivas da proposta final do edifício.

\section{REFERÊNCIAS}

ALVES, André. Todo brasileiro merece nível "A": habitação multifamiliar energeticamente eficiente para o programa Minha Casa Minha Vida. Dissertação de Mestrado Profissional. PPAPMA, UFRN, Natal, 2012.

. Minha Casa Minha Vida. CAIXA ECONOMICA FEDERAL (Ed.). Brasília: Ministério das Cidades, 2010.

KEELER, Marian ; BURKE, Bill. Fundamentos de projetos de edificações sustentáveis. Trad. Alexandre Salvaterra. Porto Alegre: Bookman, 2010.

COMITÊ GESTOR DE INDICADORES E NÍVEIS DE EFICIÊNCIA ENERGÉTICA et al. RTQ-R. Regulamento Técnico da Qualidade do nível de Eficiência Energética de Edifícios Residenciais, 2011.

JOHN, V. M. P., RACINE TADEU ARAÚJO. Selo Casa Azul: boas práticas para habitação mais sustentável. São Paulo: Páginas \& Letras, 2010. PEÑA, W.; PARSHALL, S. Problem seeking : an architectural programming primer. 4th. ed. New York: Wiley, 2001.

NOTA DO EDITOR (*) O conteúdo do artigo e as imagens nele publicadas são de responsabilidade do(s) autor(es).

\section{FIGURAS}

Figura 1 - Procedimentos metodológicos

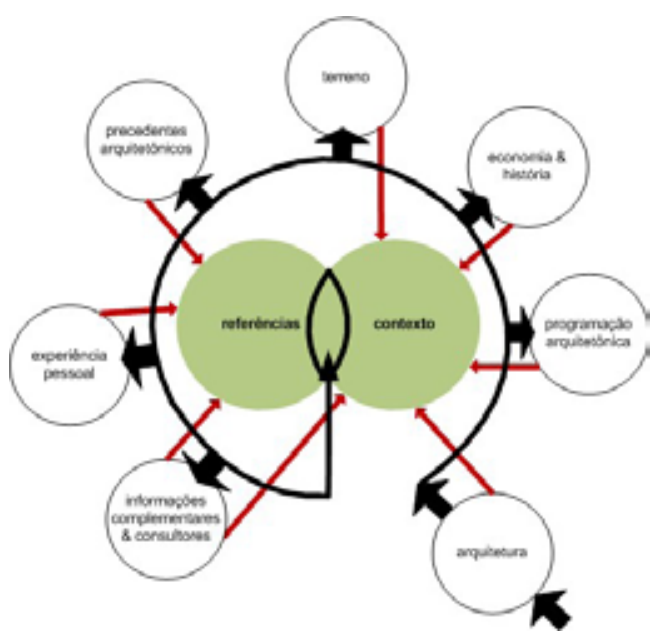

Fonte: adaptado de Fernandez (2011)
Figura 2 - Croquis de estudo preliminar: fachada voltada para Sudeste.

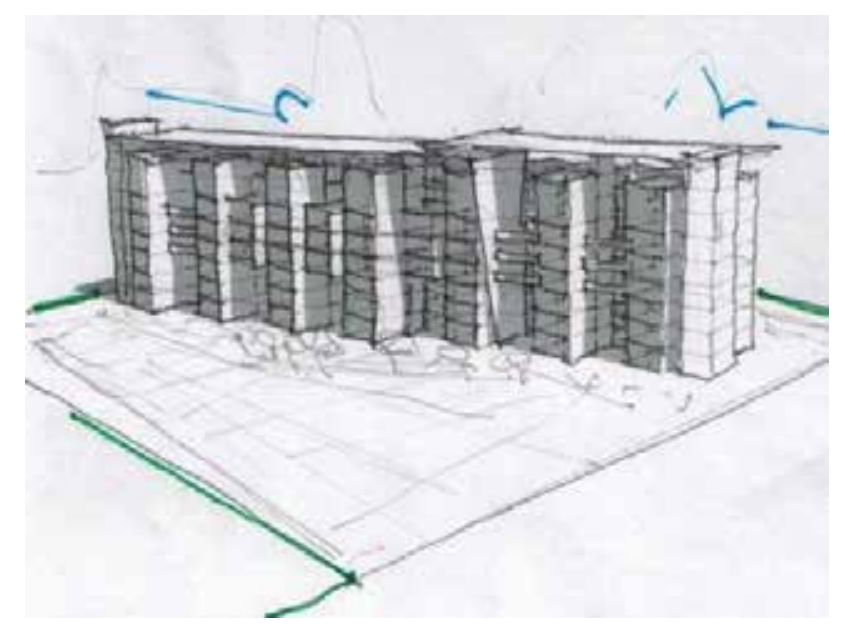

Fonte: Alves, 2012. 
Figura 3 - Croquis de planta baixa da evolução do partido adotado.
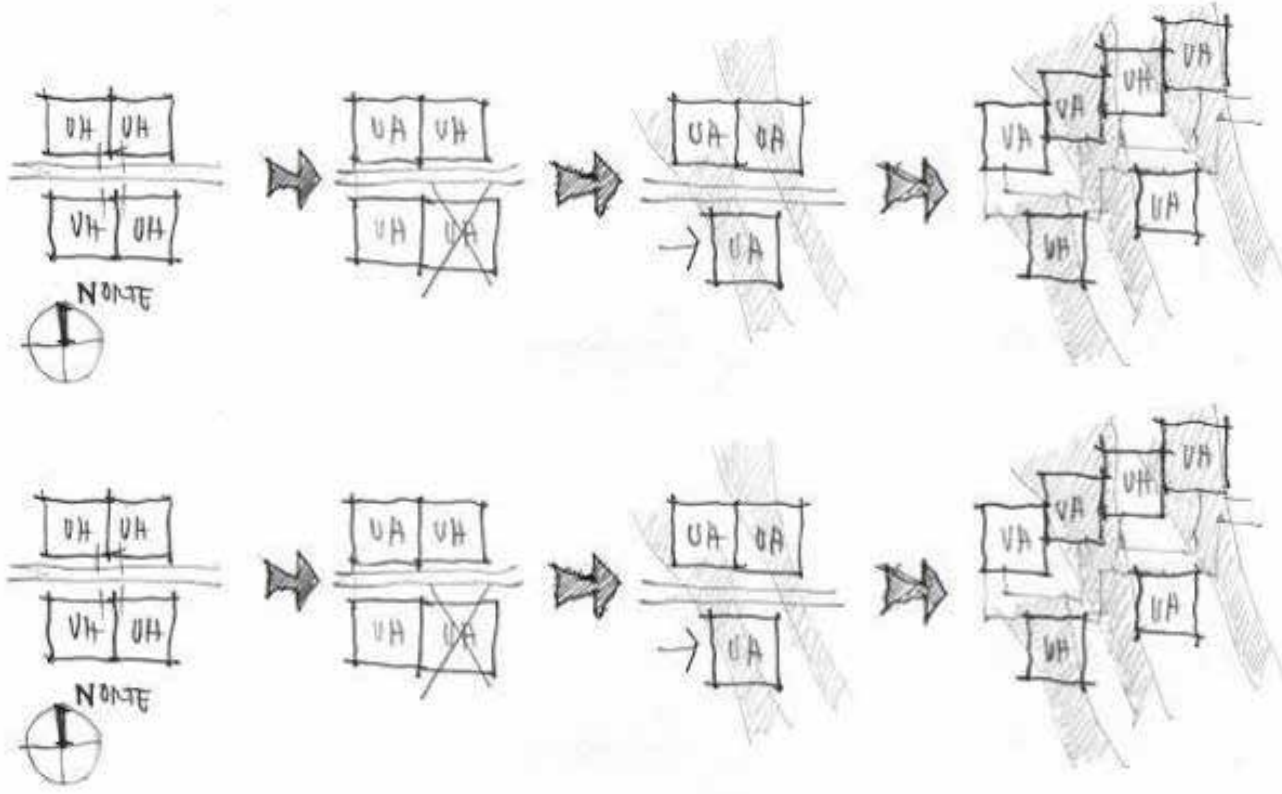

Fonte: Alves, 2012.

Figura 4 - Fotografia de maquete física esquemática.

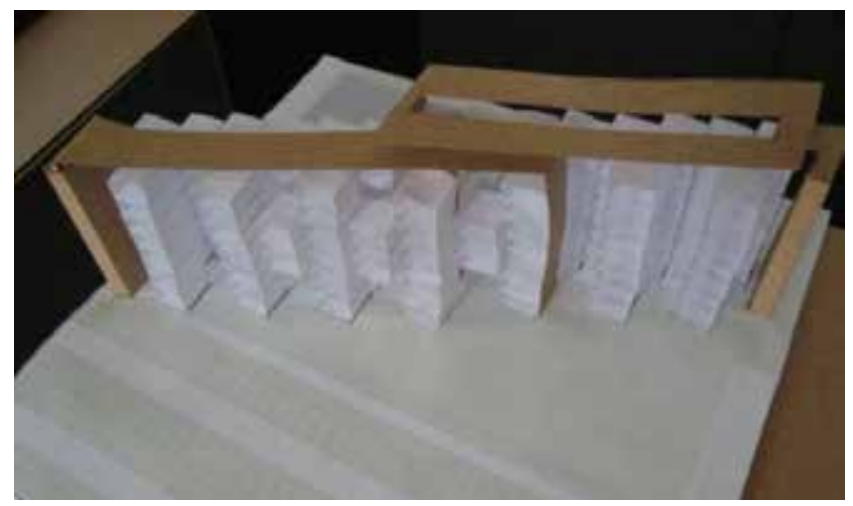

Fonte: Alves, 2012.
Figura 5 - Simulação CFD para o pavimento tipo com incidência a $105^{\circ}$

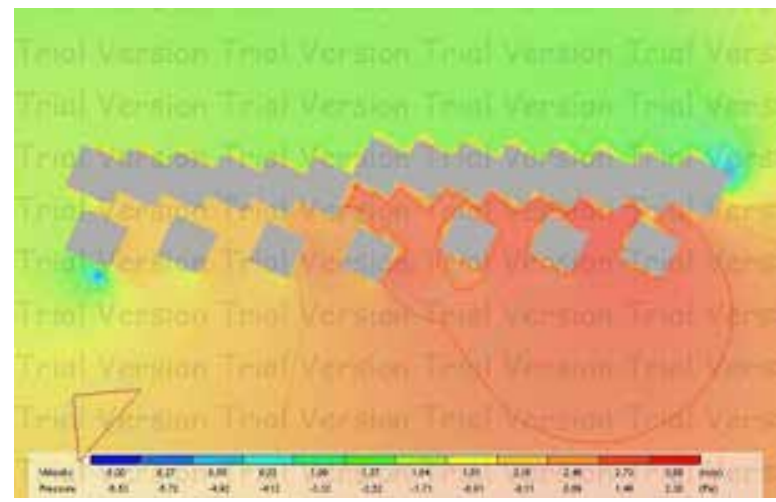

Fonte: Alves, 2012.

Figuras 6 - Habitação Multifamiliar para o MCMV

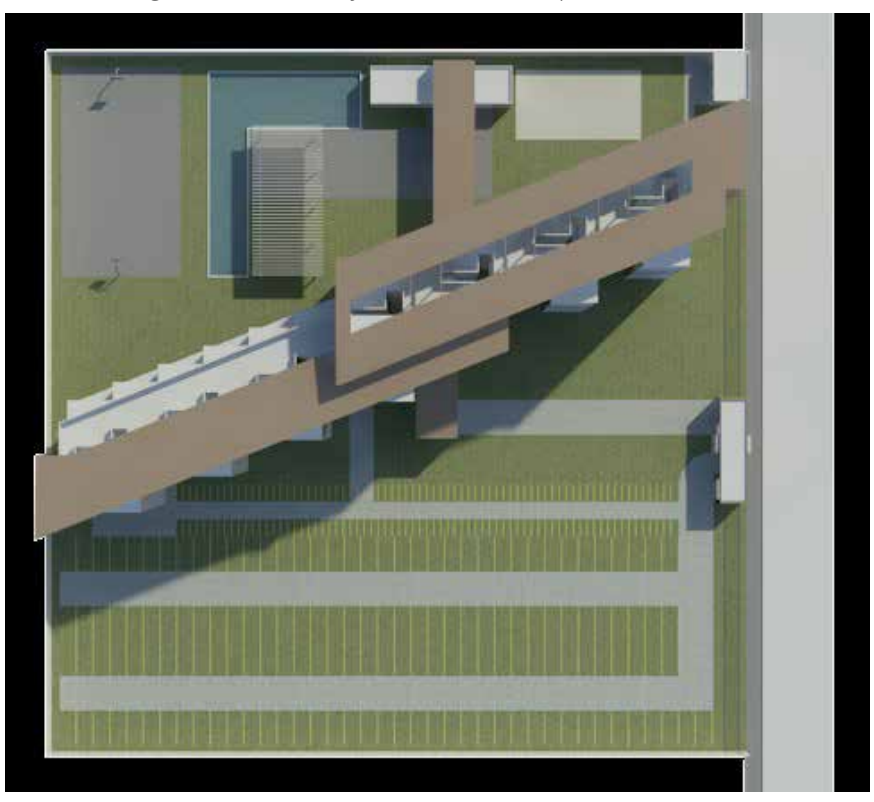

Fonte: Alves, 2012 
Figuras 7 - Habitação Multifamiliar para o MCMV

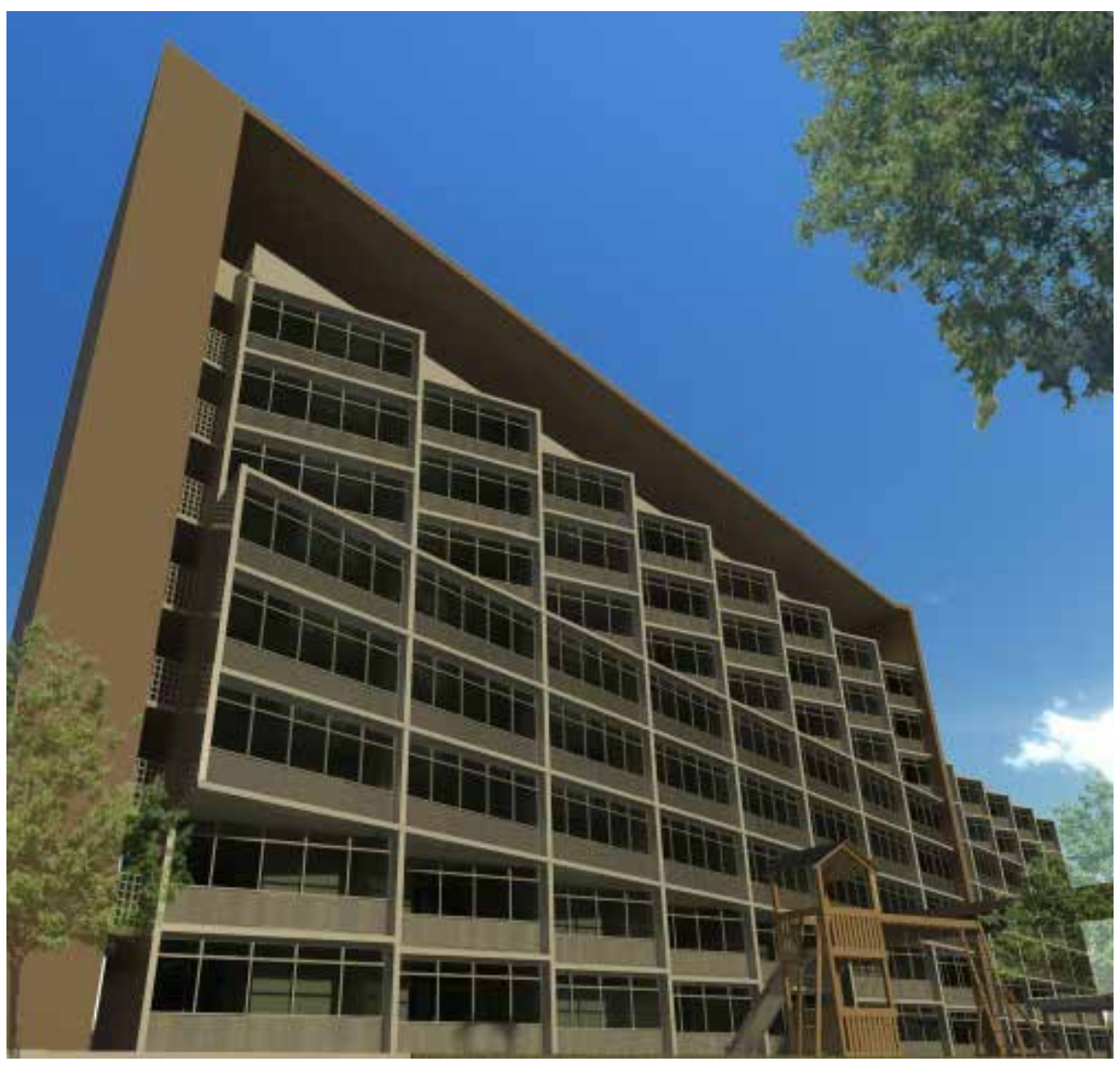

Fonte: Alves, 2012.

Figuras 8 - Habitação Multifamiliar para o MCMV

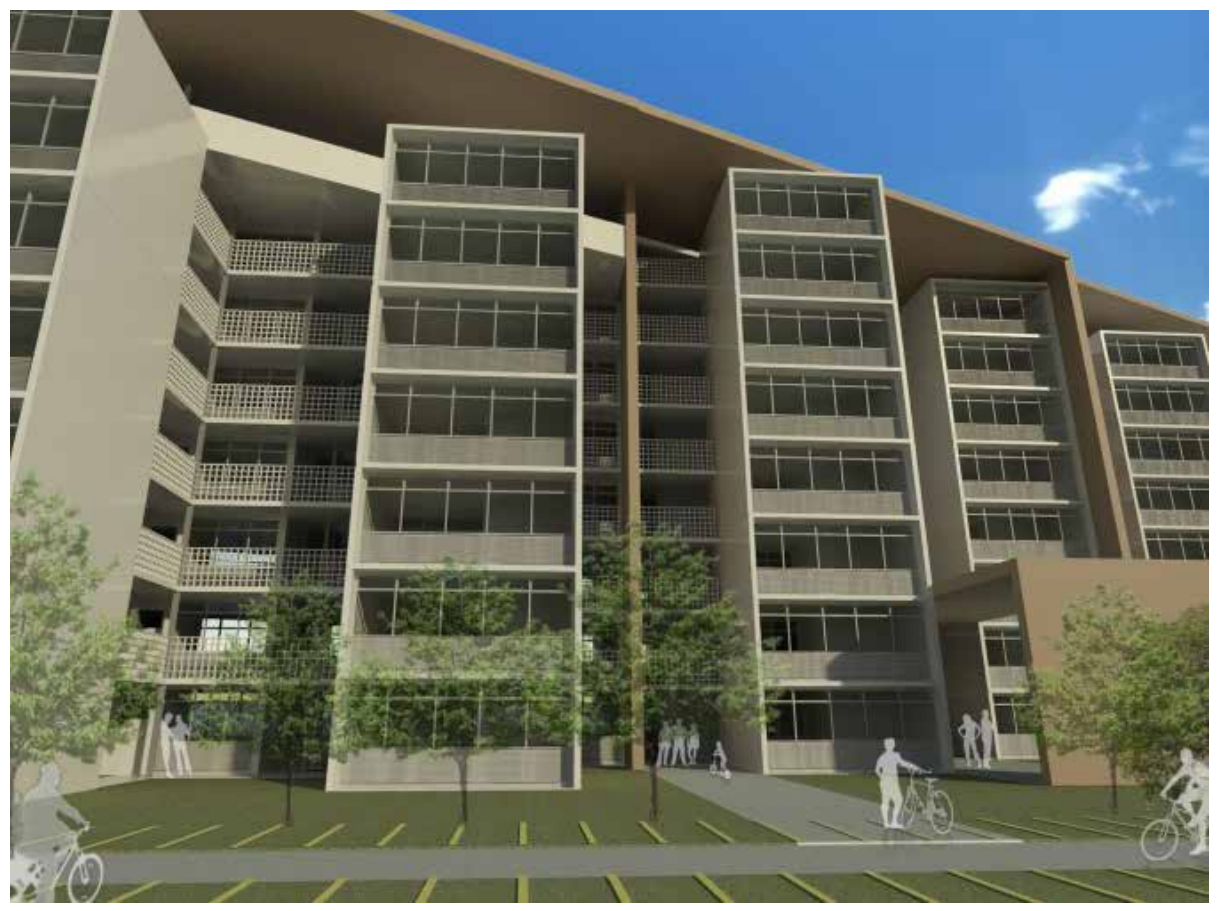

Fonte: Alves, 2012. 


\title{
PROPOSTA DE HABITAÇÃO DE INTERESSE SOCIAL COM ÊNFASE NO CONFORTO TÉRMICO PARA A ZONA BIOCLIMÁTICA-8
}

\section{MONTEIRO, VERNER MAX LIGER DE MELLO}

\author{
Arquiteto, MsC., Professor IFRN; Email: verner.monteiro@ifrn.edu.br \\ Dissertação desenvolvida no Mestrado Profissional em Arquitetura, Projeto e Meio Ambiente da UFRN \\ Orientador: Maísa Veloso; Co-orientador: Aldomar Pedrini
}

\section{RESUMO EXPANDIDO}

Este texto apresenta um estudo que teve como temática a Habitação de Interesse Social (HIS), com ênfase em demandas de conforto térmico, adequadas à realidade do município de Macaíba/RN, pertencente à Zona Bioclimática 8 (ZB-8). As questões relacionadas ao conforto térmico em HIS são muitas vezes esquecidas, pelo que se observa na trajetória brasileira de produção de habitação para a população de baixa renda. Talvez a explicação para este fato seja que a adoção de um projeto de bom desempenho térmico está equivocadamente relacionada ao aumento significativo de custos na construção da habitação. A simples adoção de diretrizes considerando as normas atuais de desempenho térmico em edificações já seria o suficiente para obter ganhos significativos em projetos de baixo custo. Indo além dessa estratégia, testar as certificações por métodos prescritivos e de simulação computacional subsidiaria ainda mais o desenvolvimento da ideia, embasando cada vez mais a tomada de decisões por parte dos arquitetos projetistas.

Considerando a possibilidade de elaboração de uma nova proposta, o objetivo geral foi demonstrar que é possível alcançar níveis de desempenho térmico adequados em HIS sem ultrapassar os limites orçamentários impostos pelos programas habitacionais. O método utilizado incluiu, além de outros itens, o estudo de normas e literatura aplicáveis ao tema, pesquisa dos materiais e sistemas construtivos, e suas possíveis aplicações, de modo a subsidiar a elaboração do projeto. Nesse contexto, surgiu a proposta de um conjunto habitacional, para a implantação de 50 residências de interesse social (Figura 1). O processo de projetação passou por uma fase evolutiva que compreendeu quatro estudos tipológicos, que considerou as variáveis levantadas priorizando o desempenho térmico, a qualidade espacial e estética, além do custo de construção das Unidades Habitacionais, tendo sido ponderados os aspectos envolvidos em cada uma das soluções.

O partido urbanístico apresenta vias orientadas no sentido leste-oeste e lotes no sentido norte-sul. As edificações são locadas no sentido transversal, adquirindo a orientação ideal. Outra estratégia adotada visando uma melhor captação dos ventos foi o desencontro entre os alinhamentos dos lotes. Assim, as esteiras de vento não interferem nas edificações adjacentes, contribuindo para a recuperação da velocidade do vento originais da região. Quanto à unidade habitacional, esta ocupa um lote padrão de 116,25 m², acima dos 104,00 $\mathrm{m}^{2}$ exigidos pela Lei municipal. Cada habitação possui área construída de $44,78 \mathrm{~m}^{2}$ e sua distribuição espacial foi definida possibilitando ampliações futuras e contemplando outros itens de ordem técnica e cultural. Os muros dos lotes estão limitados às laterais e fundos, fazendo com que seja maximizada a interação com o meio urbano, permitindo aos moradores ligação direta entre espaço privado e público (Figura 2).

A partir do estudo preliminar, foi realizado estudo de aferição dos resultados de desempenho térmico, que incluiu a simulação de ventilação natural e de simulação térmica, mecanismo de confirmação das diretrizes aplicadas ao projeto. Segundo Bittencourt (2005), a diferença de pressão é a força motriz para a ventilação. Assim, é possível predizer que, onde ocorrer essa diferença, haverá movimento de ar no interior daquele ambiente. A partir disso, foram encontradas as diferenças de pressão extraídas em processo de simulação CFD (Computacional Fluid Dynamics), gerando compreensão do funcionamento do movimento de ar no conjunto habitacional (Figuras 3 e 4).

De uma maneira ampla, os resultados apresentados mostram altas taxas de renovação de ar, ultrapassando as 120 trocas de ar por hora na maior parte das horas do ano. Isso se reflete na remoção da carga térmica adquirida pela edificação durante o dia através de sua envoltória (GIVONI, 1998). A partir dos resultados 
gerais apresentados, procedeu-se ao estudo comparativo de três modelos de habitação, descritos a seguir e derivados dos estudos realizados, com a finalidade de fazer uma verificação de desempenho geral de cada edificação, dos quais foram extraídas simulações de desempenho térmico. Os resultados foram aplicados em gráfico idealizado por Negreiros (2010), que mostra, hora a hora, qual a condição térmica predominantemente encontrada: frio, conforto, conforto com ventilação ou calor.

Tipo "A": Projeto de edificação executada pela Prefeitura em conjunto habitacional de 60 casas, com área construída de 46,67 m², formato compacto e materiais/sistemas construtivos tradicionais.

Tipo “B”: Projeto de edificação proposta, para conjunto habitacional de 50 casas, com área construída de 44,78 m², implantação alongada, e materiais/sistemas construtivos tradicionais.

Tipo “C": Projeto de edificação com área e geometria idêntica ao tipo "B", e uso de materiais/sistemas construtivos alternativos: telha sanduíche de poliuretano para a cobertura; alvenaria pré-moldada armada e Painel Wall, para as paredes de vedação.

Através de um Quadro Comparativo (Figura 5) em que são detalhados os tipos, foi possível listar as propriedades de cada um e verificar como ficou o comportamento térmico individualmente.

A edificação Tipo "B" apresenta o novo projeto. Com os mesmos materiais tradicionais aplicados no Tipo " $\mathrm{A}$ ", buscouse o aprimoramento, especialmente, da envoltória em sua capacidade de captação de ventilação natural. O Tipo "C" (Figuras 6 e 7), por sua vez, utiliza o novo projeto incorporando materiais mais eficientes, com o intuito de alcançar melhores índices de desempenho térmico, especialmente por propriedades como menor transmitância térmica.

Quanto à questão térmica, avaliando todos os tipos, é possível observar que as áreas vermelhas do gráfico, responsáveis pela indicação da sensação de calor, são drasticamente diminuídas no Tipo " $\mathrm{C}$ ", em relação às demais. Os resultados referentes aos custos das edificações indicam que o Tipo " $\mathrm{C}$ " é, de fato, mais caro que o Tipo "A" (diferença de 23\%). Os principais fatores que causaram a alta no preço foram também aqueles que propiciaram o aumento na eficiência térmica da edificação. O Tipo "B" ficou $\mathrm{R} \$ 3.799,16$ mais barato que o Tipo " $\mathrm{C}$ " em virtude da utilização de materiais tradicionais. Essa diferença de custo representou um melhor desempenho térmico em favor deste último, resultando em uma edificação melhor adaptada à Zona Bioclimática 8 e com custo total dentro dos limites do orçamento do programa habitacional "PSH". No que diz respeito à ventilação natural, os resultados dos tipos "B" e "C" são iguais, por se tratar de projeto com mesma geometria, não tendo a alteração dos materiais da envoltória interferência na ventilação natural. Já na casa Tipo " $\mathrm{A}$ ", é apresentada, na maioria das horas do ano, taxa de trocas de ar por hora que varia entre 1 e 60, nos Tipos de habitação "B" e " $C$ " esse número é maior que 120 na maior parte do ano, benefício gerado efetivamente pela variável geometria.

Os resultados obtidos no estudo apontam que é necessário que o arquiteto tenha a liberdade de associar soluções de projeto a materiais adequados, buscando resultados de desempenho térmico mais adequados à condição climática local, não obstante à consideração de aspectos orçamentários e de infraestrutura urbana das cidades em que serão instalados conjuntos habitacionais de interesse social.

\section{REFERÊNCIAS}

ASSOCIAÇÃO BRASILEIRA DE NORMAS TÉCNICAS. NBR 15220-3 - Desempenho térmico de edificações. Parte 3: Zoneamento bioclimático brasileiro e diretrizes construtivas para habitações unifamiliares de interesse social. Rio de Janeiro, 2005.

BITTENCOURT, Leonardo Salazar; CÂNDIDO, C. Introdução à ventilação natural. Maceió: EDUFAL, 2005.

DESIGNBUILDER SOFTWARE LTD. DesignBuilder. 2000-2005.

GIVONI, B. Climate considerations in buildings and urban design. New York: John Wiley e Sons, 1998.

MONTEIRO, Verner. Por uma moradia termicamente confortável. Proposta de Habitação de Interesse Social com ênfase no conforto térmico. Dissertação de Mestrado apresentada ao Programa de Pós-Graduação em Arquitetura e Urbanismo / Mestrado Profissional em Arquitetura, Projeto e Meio Ambiente. Natal, 2012.

NEGREIROS, Bianca de Abreu. Análise de métodos de predição de desempenho térmico de habitação em clima quente-úmido, com condicionamento passivo. Dissertação de Mestrado Acadêmico apresentada aoPrograma de Pós- graduação em Arquitetura e Urbanismo, Universidade Federal do Rio Grande do Norte. Natal, 2010.

NOTA DO EDITOR (*) O conteúdo do artigo e as imagens nele publicadas são de responsabilidade do(s) autor(es). 


\section{FIGURAS}

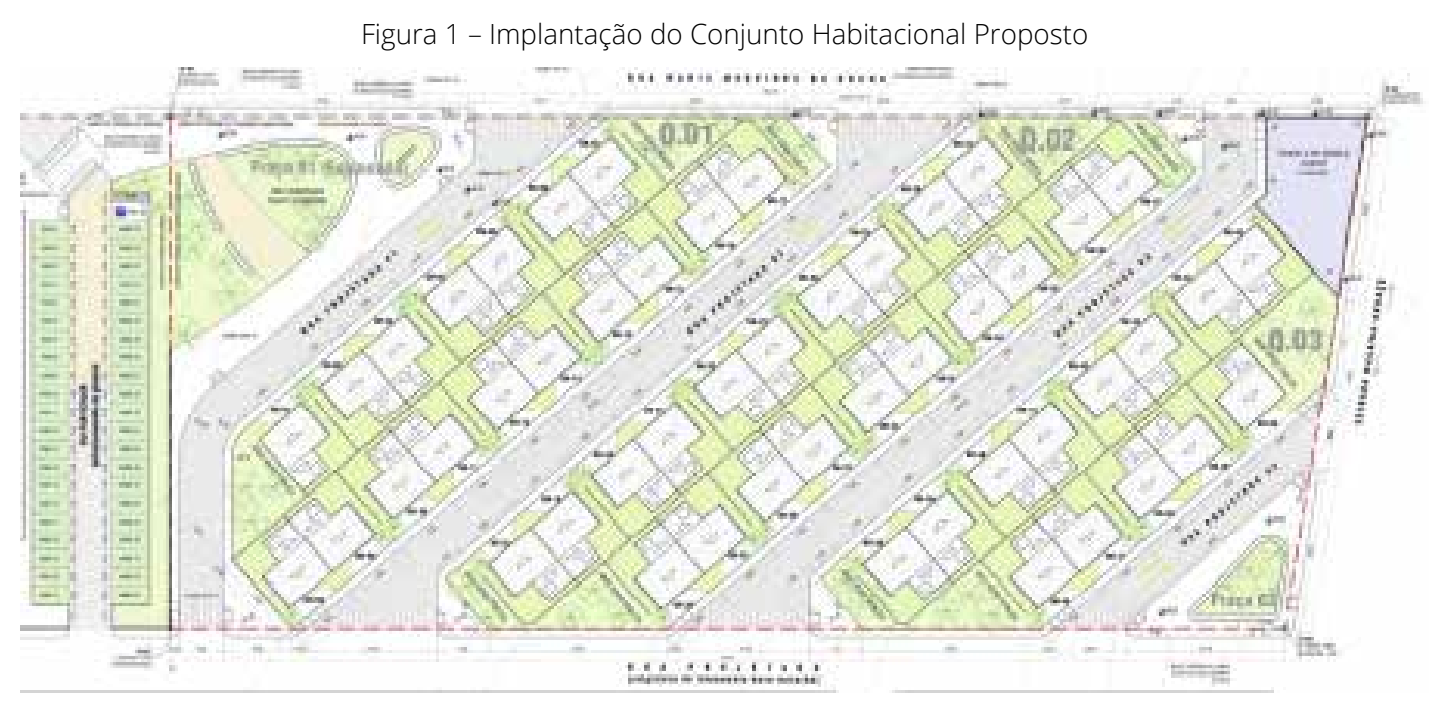

Fonte: MONTEIRO, 2012.

Figura 2 - Perspectiva a partir da via pública.

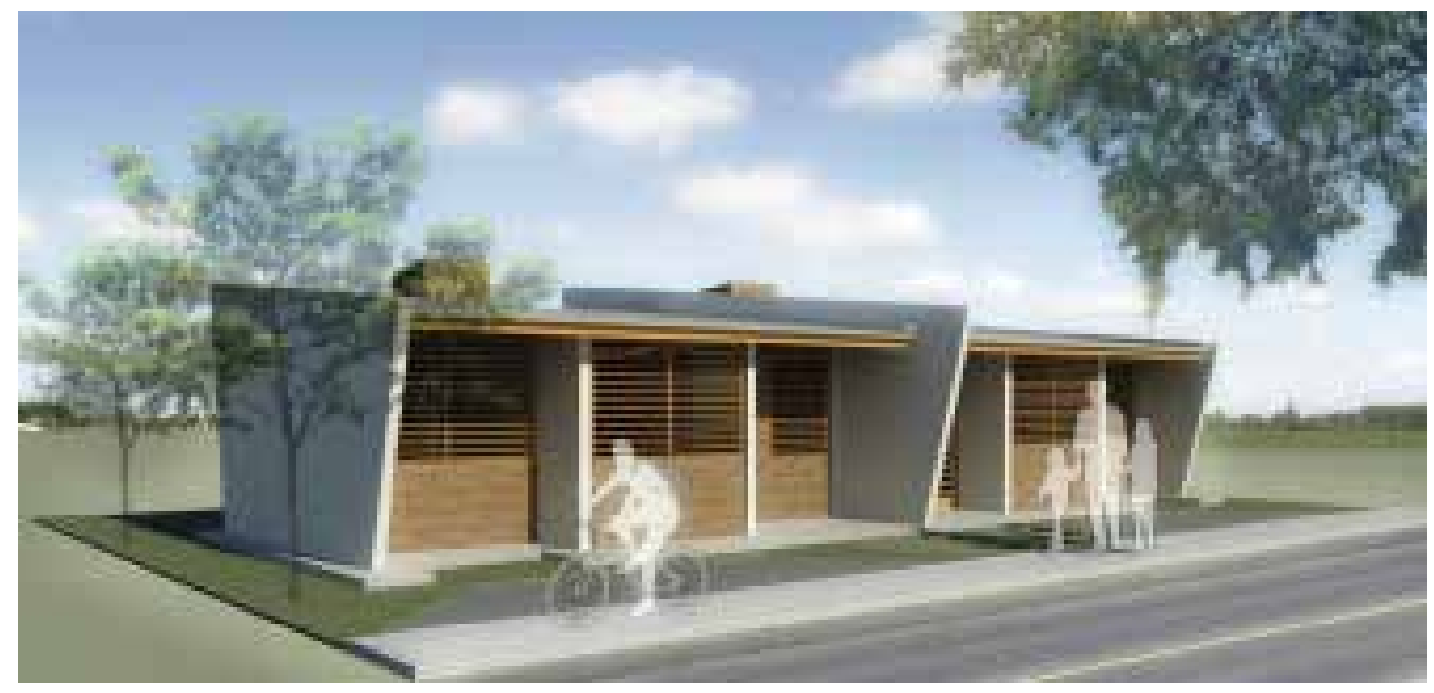

Fonte: MONTEIRO, 2012.

Figura 2 - Perspectiva a partir da via pública.

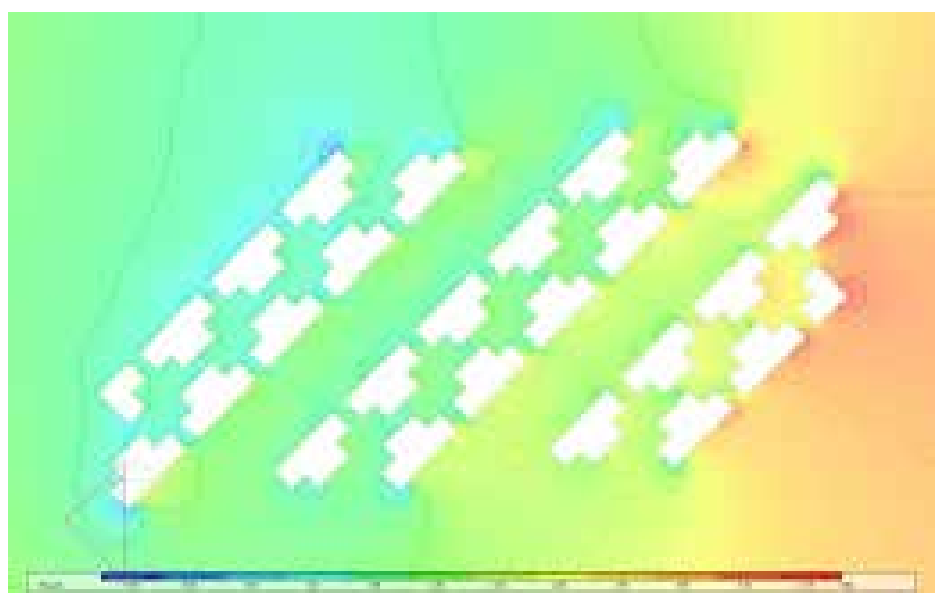

Figuras 3 - Campos de pressão a 135 (ventilação predominante) na altura do centro das janelas. 
Figura 4 - Trocas de ar, hora a hora, ao longo do ano.

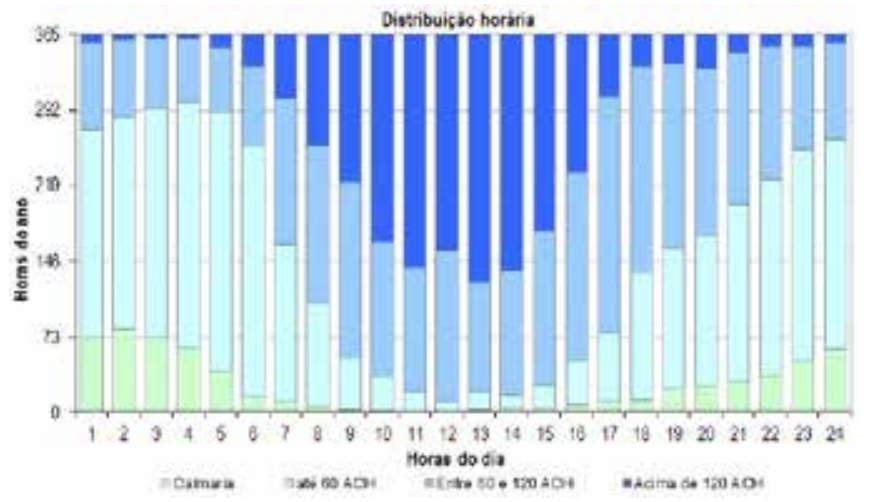

Fonte: MONTEIRO, 2012.

Figura 5 - Quadro Comparativo.

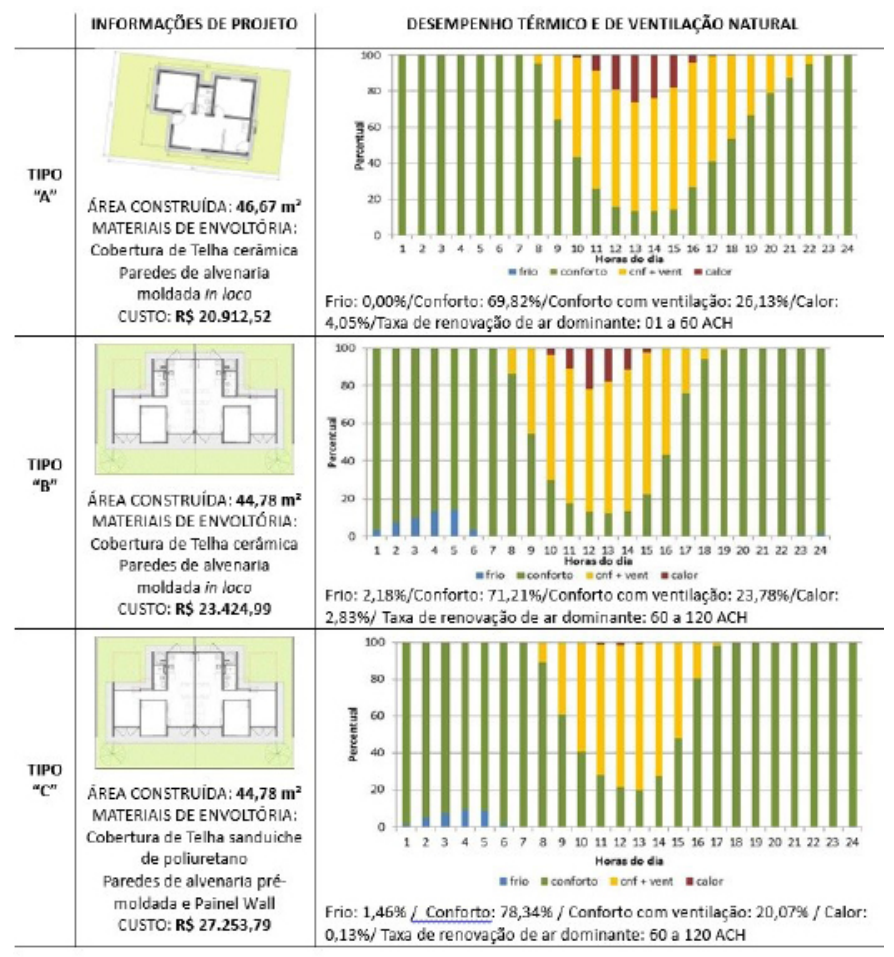

Fonte: MONTEIRO, 2012.

Figura 6 - Planta baixa perspectivada da casa Tipo C.

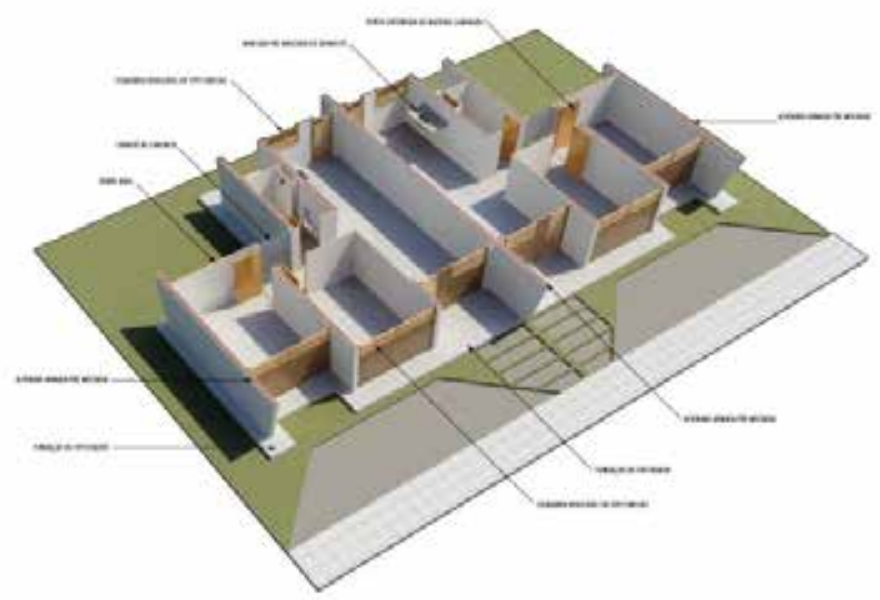

Fonte: MONTEIRO, 2012. 


\section{PROCESSO DE CONCEPÇÃOO DO PROJETO ARQUUTETÔNICO PARA UMA ESCOLA DE TURISMO}

\section{DANTAS, PETTERSON MICHEL}

Arquiteto, MSC., Superintendência de Infraestrutura da UFRN; email: pettersonarq@gmail.com Dissertação desenvolvida no Mestrado Profissional em Arquitetura, Projeto e Meio Ambiente da UFRN Orientadora: Edna Moura Pinto ; Co-orientadora: Solange Galarça Goulart

\section{RESUMO EXPANDIDO}

O projeto de uma Escola de Turismo para a Universidade Federal do Rio Grande do Norte foi resultado das reflexões empreendidas durante o curso do Mestrado Profissional em Arquitetura, Projeto e Meio Ambiente da UFRN. O trabalho abordou a racionalização do consumo de água aplicada ao desenvolvimento de um projeto arquitetônico para um edifício institucional em região de clima quente e seco e baixa disponibilidade hídrica - a região Seridó do Estado.

Do ponto de vista metodológico, além das etapas usualmente presentes em um projeto arquitetônico definição de programa e identificação de condicionantes - o processo de concepção foi estruturado a partir da leitura de textos de Favero e Passaro (2005) e Maciel (2003). Assim, seu desenvolvimento se baseou em conceitos que refletiram uma resposta ao lugar (introversão), ao programa arquitetônico (coletivização) e às formas de construir (segmentação). Ainda adotando-se o raciocínio analógico, discutido por Florio e Tagliari (2009) como uma forma de síntese de problemas complexos, foi construída uma metáfora conceitual para o projeto, comparando a edificação projetada a um oásis.

Um oásis é um ambiente em um deserto onde geralmente há uma nascente de água doce e vegetação, o que consequentemente resulta em aglomeração humana. Tendo-se em consideração o cuidado com a gestão da água e principalmente os dois primeiros conceitos adotados para o projeto - introversão e coletivização considera-se apropriada a imagem do oásis como um reservatório de água em região de escassez, um lugar que agrega população e que tem um clima diferente do deserto que o rodeia, qualidades que se buscaram no projeto da Escola de Turismo. Após estabelecimento de conceitos, foram definidas soluções espaciais que poderiam enfatizar as intenções do projeto, expressas no quadro 1:

Quadro 1: Relação entre conceitos estabelecidos e soluções espaciais planejadas.

\begin{tabular}{ll}
\hline CONCEITO & SOLUÇÕES ESPACIAIS \\
\hline Introversão (resposta ao & Edificação organizada em torno de um pátio \\
\cline { 2 - 2 } clima quente e seco) & Criação de espaços de transição entre interior e exterior \\
\cline { 2 - 2 } Coletivização & Aberturas voltadas para circulações e não diretamente para o exterior \\
\hline $\begin{array}{l}\text { Disposição de circulações horizontais e verticais com vista para o interior } \\
\text { da edificação, propiciando a visão de outras partes do prédio e encontros } \\
\text { de usuários }\end{array}$ \\
\cline { 2 - 2 } $\begin{array}{l}\text { Disposição de espaços de convívio ou coletivos em pontos onde as } \\
\text { circulações se cruzam, deixando-os mais acessíveis }\end{array}$ \\
\hline $\begin{array}{l}\text { Divisão do edifício em etapas construtivas, permitindo a execução parcial } \\
\text { em função da disponibilidade de recursos financeiros }\end{array}$ \\
\cline { 2 - 2 } & $\begin{array}{l}\text { Adoção de dois sistemas construtivos: estrutura de concreto intercalada } \\
\text { por espaços que funcionam como separadores de etapas construtivas, } \\
\text { executados com componentes metálicos }\end{array}$ \\
\hline
\end{tabular}


O estudo preliminar que deu origem ao projeto final para a Escola de Turismo foi construído a partir de um prisma e uma sequência de movimentos aplicados a este volume para se chegar às condições desejadas para abrigar os espaços do programa arquitetônico. O princípio do estudo foi um espaço totalmente isolado do exterior - o extremo do conceito de introversão, como "uma caixa virada para baixo". Para dar acesso à edificação, uma das pontas da "caixa" foi erguida e sua extremidade oposta foi consequentemente rebaixada (Figura 1).

Foram previstas circulações em todo o perímetro da edificação, semelhante às casas de fazenda do sertão, que geralmente são cercadas por alpendres, os quais servem como circulações e espaço para descanso e lazer (Figura 2). Visto que a "caixa" foi levantada em uma das pontas, as circulações externas do volume foram transformadas em rampas.

O gesto de subir o canto da caixa também foi responsável pela criação de uma cobertura que concentra o fluxo de água da chuva no canto Nordeste do prédio. Em função disso, planejou-se instalar nesse ponto os reservatórios de água pluvial e a torre d'água, que abastecem o prédio. Unificado à estrutura da torre, planejou-se a instalação de um cata-vento para bombear a água, mecanismo utilizado no sertão nordestino e, nesse caso, empregado também como um elemento simbólico (Figura 3).

Sob o ponto de vista estrutural, o prédio pode ser entendido como blocos executados em concreto, intercalados por faixas em estrutura metálica. Esta solução surgiu como resposta ao conceito de segmentação, possibilitando a construção em etapas. Nesse contexto, as áreas metálicas entre blocos atuam como grandes juntas de dilatação que separam as etapas construtivas (Figura 2).

O tratamento das fachadas considerou os dados obtidos no estudo de insolação. Nas fachadas Norte e Sul foram dispostas as aberturas da edificação, protegidas por uma marquise e brises, enquanto a Oeste foi tratada como um plano totalmente fechado (Figura 4). Os brises das fachadas Norte e Sul foram desenvolvidos a partir de placas dispostas em diagonal, suportadas por tubos fixados em uma grelha metálica. As cantoneiras de reforço das placas permitiram a formação de um vazio em forma de elipse e o desenho final assumiu uma discreta homenagem aos muxarabis, trançados de palhas e bordados da região do Seridó (Figura 5).

\section{REFERÊNCIAS}

DANTAS, Petterson Michel. Projeto de um edifício para fins educacionais com foco na racionalização do consumo de água. Dissertação de Mestrado apresentada ao Programa de Pós-Graduação em Arquitetura e Urbanismo / Mestrado Profissional em Arquitetura, Projeto e Meio Ambiente. Natal, 2012.

FAVERO, Marcos; PASSARO, Andrés. Senso e conceito no constructo da disciplina projetual: análise projetual como instrumento de trabalho. In: Anais do Projetar 2005: /l Seminário sobre Ensino e Pesquisa em Projeto de Arquitetura, Rio de Janeiro, dez. 2005.

FLORIO, Wilson; TAGLIARI, Ana. Projeto, criatividade e metáfora. Disponível em: shttp://redalyc.uaemex.mx/src/inicio/ArtPdRed. j=193614470004>. Acesso em: 1 abr. 2011.

MACIEL,CarlosAlberto.Arquitetura, projetoe conceito. Disponível em: $\leq$ http://www.vitruvius.com.br/revistas/read/arquitextos/04.043/633>. Acesso em: 1 abr. 2011.

NOTA DO EDITOR (*) O conteúdo do artigo e as imagens nele publicadas são de responsabilidade do(s) autor(es). 
Figura 2 - Esquemas de circulação e de sistema construtivo - áreas com estrutura de concreto intercaladas por faixas de estrutura metálica

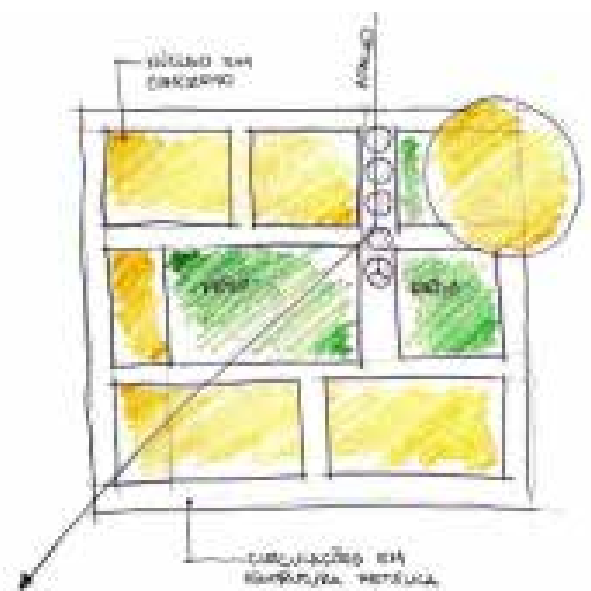

Fonte: DANTAS, 2012.
Figura 1 - Croquis de Concepção - "A caixa invertida"

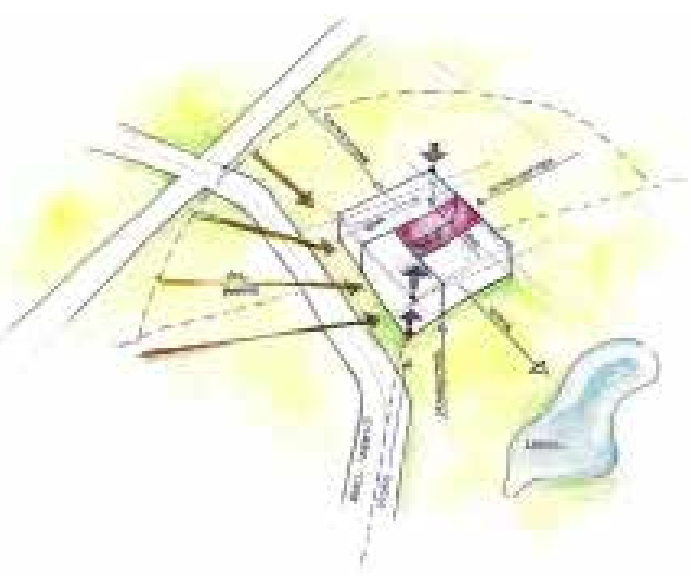

Fonte: DANTAS, 2012.

Figura 3 - Esquemas de distribuição dos usos e inserção dos reservatórios

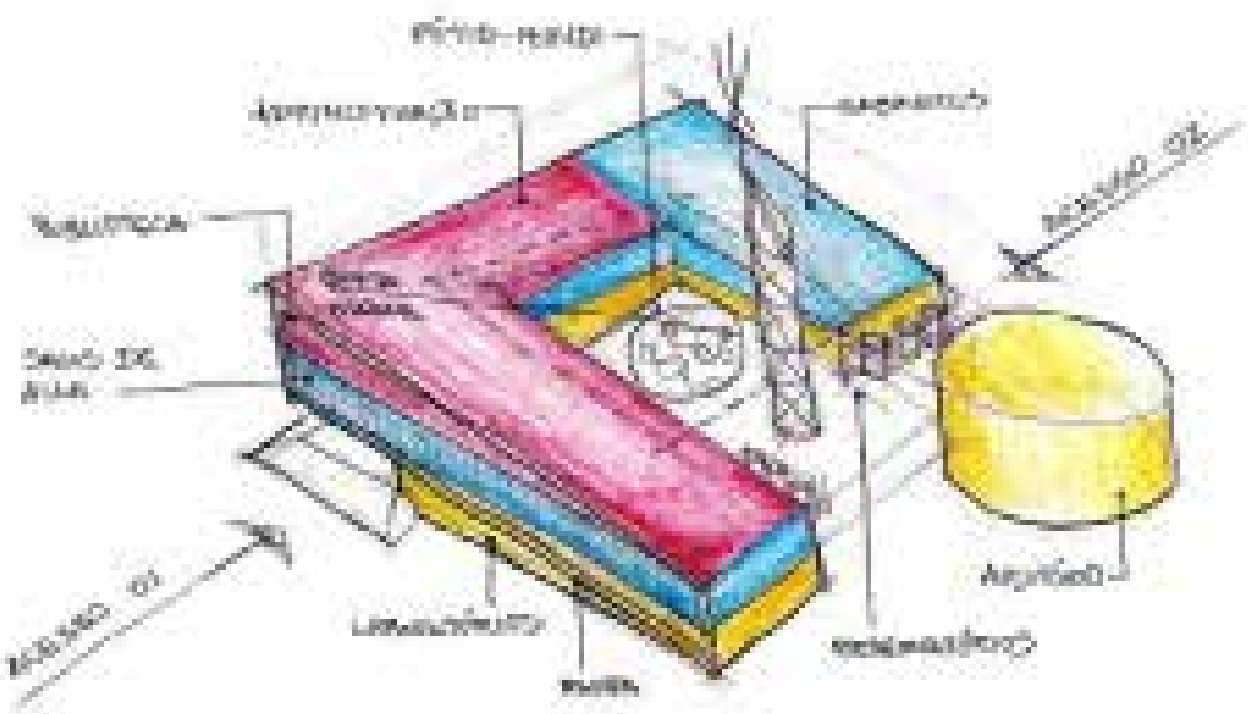

Fonte: DANTAS, 2012

Figura 4 - Perspectivas à mão livre do edifício
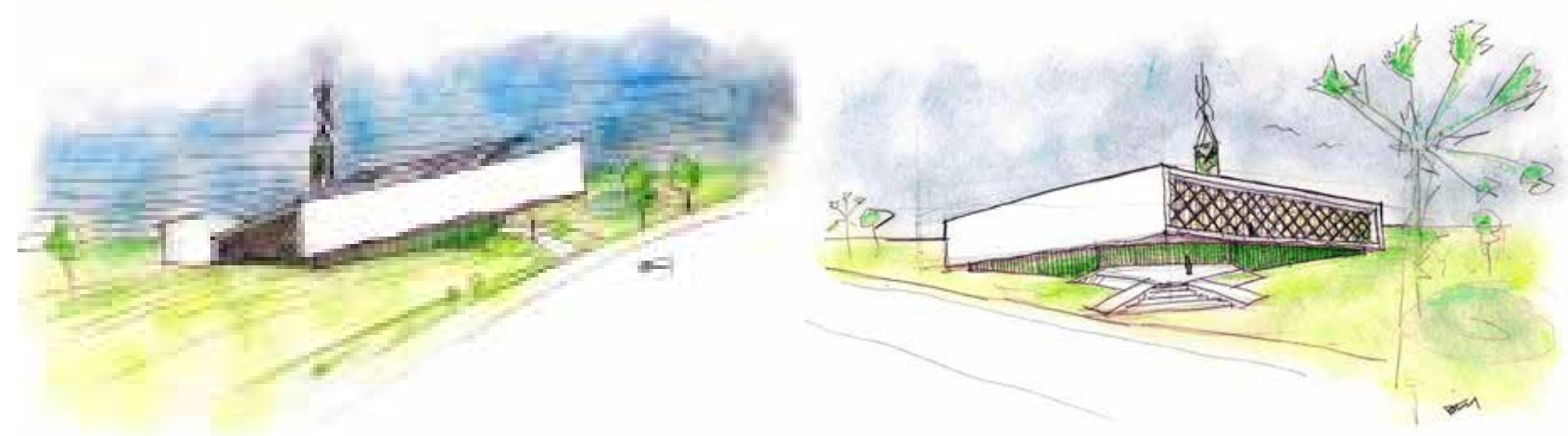

Fonte: DANTAS, 2012 
Figura 5 - Perspectivas do edifício
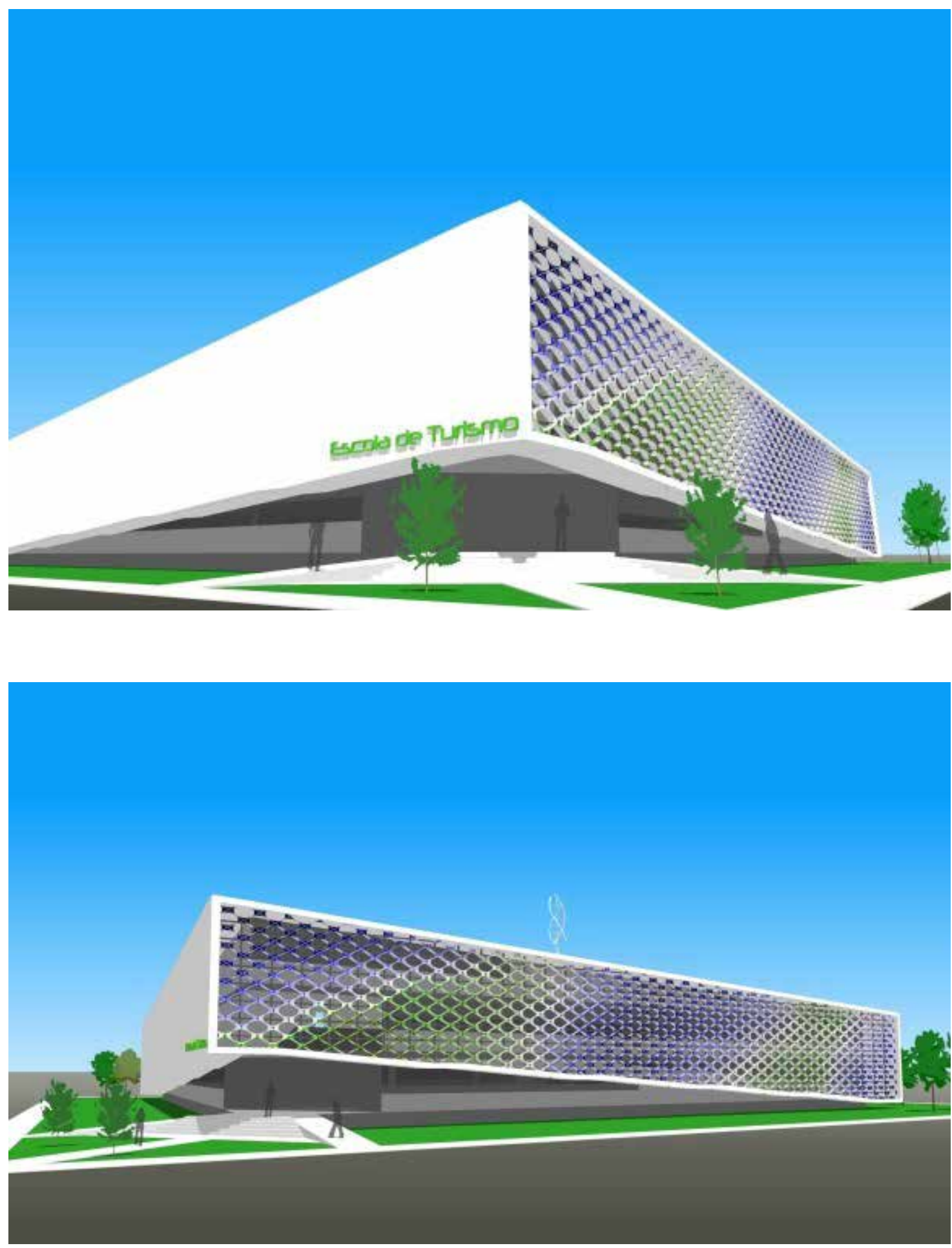

Fonte: DANTAS, 2012. 


\title{
CONDOMIINIO DE CASAS EM NATAL-RN: UM EXEMPLO DE SIINTESE PROJETUAL UTILIZANDO PRIIIĆ́PIOS DA GRAMÁTICA DA FORMA
}

\author{
CALDAS, MARIANA PIRES GURGEL \\ Arquiteta, MSC.,IDEMAVRN; Email: marigurgel@hotmail.com \\ Dissertação desenvolvida no Mestrado Profissional em Arquitetura, Projeto e Meio Ambiente da UFRN \\ Orientadora: Maísa Veloso; Co-orientador: Marcelo Tinoco
}

\section{RESUMO EXPANDIDO}

Com a intenção de se estudar e desenvolver o processo de projeto com base em uma metodologia específica, apresenta-se aqui, como produto de uma dissertação/projeto do Mestrado Profissional em Arquitetura, Projeto e Meio Ambiente da UFRN, o anteprojeto de um condomínio de casas na cidade de Natal a partir da aplicação de princípios da gramática da forma, utilizados em seu processo de concepção.

A gramática da forma é um método de projeto desenvolvido na década de 1970 por George Stiny e James Gips, utilizado tanto para a análise como para a síntese de projetos, com o objetivo de se criar um "vocabulário formal", através de operações matemáticas e/ou geométricas. No nosso trabalho, este método foi utilizado no processo de síntese de projeto, numa relação entre as subtrações formais e a programação arquitetônica das casas.

Para a definição da planta de base para uma casa, foi elaborado um programa inicial a partir do qual outros pudessem ser derivados, adequando-se a diferentes configurações familiares, identificadas nas pesquisas e estudos de referências realizados.

Dessa forma, o processo de definição dos programas arquitetônicos teve início com a elaboração de um primeiro, aqui denominado como "de base" ou "tipo A":

CASA TIPO A (programa arquitetônico de base)

Térreo (áreas úteis):

- $\quad$ Salas (jantar/ estar): 20,00 $\quad$ 20

- Cozinha: 6,00m²

- $\quad$ Área de serviço: 4,00m²

- $\quad$ BWC social: $2,40 \mathrm{~m}^{2}$

- $\quad$ Escritório: $10,00 \mathrm{~m}^{2}$
Pavimento superior (áreas úteis):

Quarto 01: 10,00m²

Quarto 02: 10,00m²

Quarto 03: 10,00m²

BWC social 01: 2,40m²

BWC quarto 02: 5,40m²

Na fase da programação arquitetônica, percebeu-se que na medida em que quartos e/ou escritório eram excluídos da planta de base (tipo A), novas configurações de plantas eram formadas, ou seja, novos programas surgiam derivados através de subtrações de ambientes do programa arquitetônico da casa A.

Após tal constatação, foi assumido o princípio da subtração, uma operação binária, em que a partir da interação entre dois elementos há o surgimento de um terceiro. Dessa forma, estabeleceu-se como elemento 1 (S1) a fachada sem subtrações, e como elemento 2 (S2), a porção da fachada correspondente ao ambiente subtraído, no caso um quarto ou escritório. O resultado seria a interação entre S1 e S2, incrementada pelo uso de marcadores, responsáveis pela remoção da simetria, possibilitando o aparecimento de diferentes composições com a aplicação de uma mesma regra (Figura 01).

Antes disso, porém, a partir da compreensão de que a subtração de ambientes poderia ser um caminho para a elaboração de novos programas arquitetônicos, foram elencados cinco tipos possíveis de programação, no que se refere ao número de quartos e à existência ou não do ambiente escritório: casas com "três quartos e um escritório" (tipo A), com "dois quartos e um escritório" (B), com "um quarto e um escritório" (C), com "três quartos" (D) e com "dois quartos" (E). 
Após a definição do grupo de programas, foi aplicada a regra inicial sobre as fachadas da casa de base (tipo A) para conferir as possibilidades de subtração geradas por cada um no que se refere à extração do ambiente posicionado na planta, no caso quarto 01, quarto 02, quarto 03 e/ou escritório, conforme as figuras 02 e 03 seguintes.

Na etapa seguinte, foram produzidas maquetes em papel cartão na escala 1/125 de todas as possibilidades de casas, respeitando os tipos de programas mencionados na Figura 03. Nesse momento, através da manipulação dos protótipos, foram elaboradas novas regras, aqui denominadas "complementares", para a definição da composição de grupos geminados, aproveitando ainda mais o potencial construtivo do terreno.

Assim, instituiu-se que nas fachadas frontais deveria haver pelo menos duas subtrações, equilibrando a relação entre cheios e vazios, e que não seria possível a existência de um vazio colado a outro.

Depois de encontrar os modelos possíveis de acordo com as regras estabelecidas, optou-se pelo desenvolvimento de três grupos geminados ( $B B, C D$ e $A E$ ), repetidos até o total de nove volumes na implantação (Figura 04):

Paralelamente, foram tomadas decisões referentes à ventilação e ao sombreamento das fachadas. Assim, com base em informações extraídas da aplicação de cartas solares sobre as casas, ficou decidido proteger as fachadas Sudeste e a Noroeste, opostas entre si, tanto com beiral como com painéis volantes à frente de cada uma, mantendo-as, porém, permeáveis aos ventos de piso a teto. Já as fachadas Sudoeste e Nordeste receberam proteção através apenas de beiral, já que seriam sombreadas horizontalmente pelas casas vizinhas (Figura 05).

Nesse ponto, cabe constatar que no processo aqui desenvolvido a programação arquitetônica inicialmente condicionou as possibilidades formais, mas, em seguida, foram as próprias regras de composição, tanto as iniciais como as "complementares", que terminaram por definir como os volumes seriam combinados.

A proposta final foi, dessa forma, composta por cinco configurações de unidades habitacionais, diferentes entre si no tocante à forma e à programação arquitetônica, distribuídas em três grupos geminados, que se repetem até o total final de nove volumes arquitetônicos. Além dos estudos de ventilação do condomínio e das simulações de sombreamento das edificações, foram realizados estudos de flexibilidade espacial e de desempenho acústico.

Um dos objetivos específicos da dissertação, o mapeamento do processo de projeto, foi composto não só pelo registro dos condicionantes formais (elaboração e aplicação de regras), mas também por aspectos físicos, ambientais, legais e de sustentabilidade no que se refere, por um lado, à otimização do sombreamento e da ventilação passiva para climas quente-úmidos e, por outro, à modulação e à racionalização da construção.

\section{REFERÊNCIAS}

CALDAS, Mariana P.G. Sobre formas e processos: projeto de um condomínio de casas a partir de princípios da gramática da forma. Dissertação (Mestrado Profissional) - Arquitetura, Projeto e Meio Ambiente, PPGAU/UFRN, Natal, 2014.

CELANI, Gabriela et al. A gramática da forma como metodologia de análise e síntese em arquitetura. Conexão - Comunicação e Cultura, Caxias do Sul, v. 5, n. 10, p.182-197, jul/dez, 2006.

HOLANDA, Armando de. Roteiro para construir no Nordeste: Arquitetura como lugar ameno nos trópicos ensolarados. Recife: Universidade Federal de Pernambuco, 1976.

LAWSON, Bryan. Como arquitetos e designers pensam. Cubatão: Oficina de Textos, 2011. Tradução de Maria Beatriz Medina.

VAZ, Carlos Eduardo Verzola. As linguagens compositivas de Roberto Burle Marx: aplicação e caracterização pela Gramática da Forma. Dissertação (Mestrado) - Curso de Engenharia Civil, Faculdade de Engenharia Civil, Arquitetura e Urbanismo, Unicamp, Campinas, 2009.

NOTA DO EDITOR (*) O conteúdo do artigo e as imagens nele publicadas são de responsabilidade do(s) autor(es).

\section{FIGURAS}


Figura 01: Esquema da lógica utilizada para a composição da regra, baseada nos princípios da subtração e dos marcadores

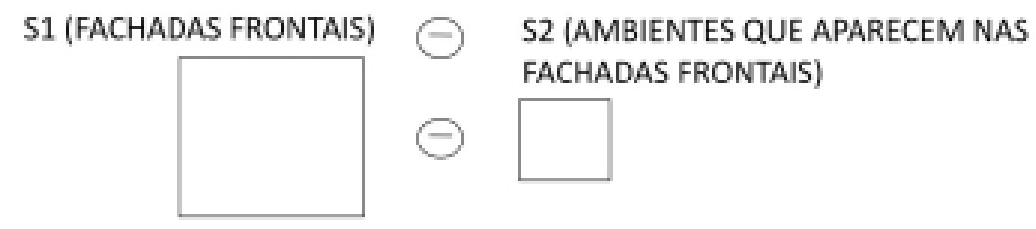

Marcadores em S1, removendo a simetria na aplicação da regra

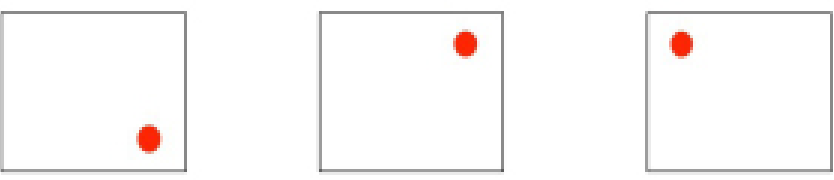

Subtração em cada fachada, de acordo com as possibilidades dos programas

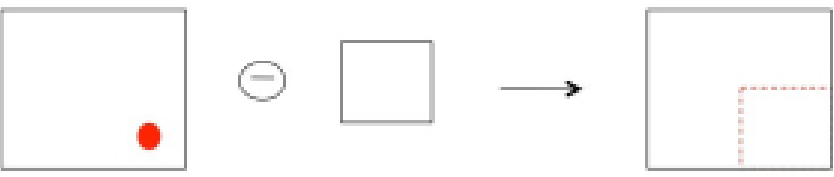

Representação da regra, através de substituiçăo

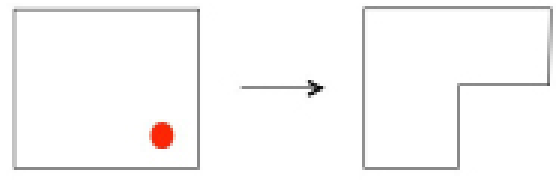

(Se A, então B)

Fonte: CALDAS, 2014

Figura 02: Em laranja, ambientes que poderiam ser subtraídos através da regra, na casa tipo A
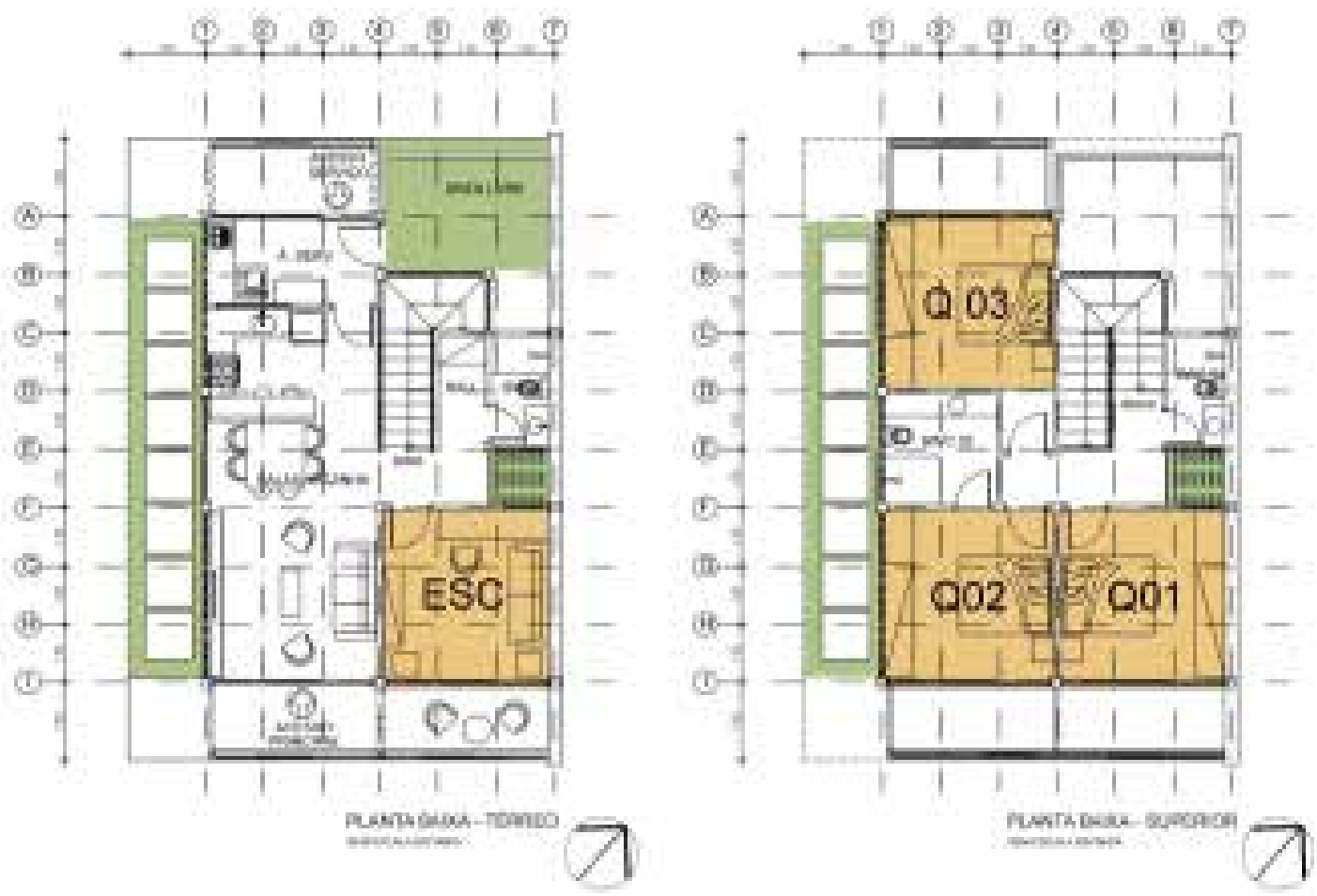

5UATRACOES POSSIUEI5

Fonte: CALDAS, 2014. 
Figura 03: Quadro explicativo da relação entre os 5 tipos de programa (retângulos coloridos à direita) e a aplicação da regra

\begin{tabular}{|c|c|c|c|c|c|c|}
\hline & FACHOAOA FAONTA & choonulearl & TERPEO & Pow sue. & Procennans & \\
\hline 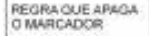 & & & 销! & 囯| & CSO+OIEsc & \\
\hline Suetracto Do Es: & ローロ & & the & GE) & 030 & A \\
\hline Suprexce ore or & $\square-\square$ & & (1) & 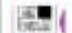 & mo & \\
\hline 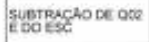 & 口ים & $\square-\square$ & है। & 50 & $a 20$ & D \\
\hline 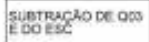 & 口- & $\square-\square$ & स्व & 둔 & $a=0$ & \\
\hline Subtracho of or & 口-口 & & 结国 & it & $020+01$ E9C & E \\
\hline Suetruceto de OSE & $\square-\tau$ & $\square-\square$ & 铇1 & Gil & D2O+01ESC & \\
\hline suetruchero de aos & & $\square-\square$ & 탐의( & $y=1$ & O20+01ECC & B \\
\hline $\begin{array}{l}\text { Suerrecho do ool } \\
\text { Ecet oxs }\end{array}$ & $\square-\square$ & $\square-\square$ & Fel & 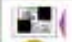 & OHQ.01ESC & \\
\hline 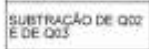 & $\square-\square$ & $\square-\Omega$ & Figl & In & $01 Q+01 E B C$ & c \\
\hline $\begin{array}{l}\text { Suerencho de oor } \\
\text { Eoto oif }\end{array}$ & $\square$ & माप & 㜔 & 9 & $010.01 \mathrm{EgC}$ & \\
\hline
\end{tabular}

Fonte: CALDAS, 2014

Figura 04: Quadro resumo com as definições programáticas depois de aplicadas todas as regras

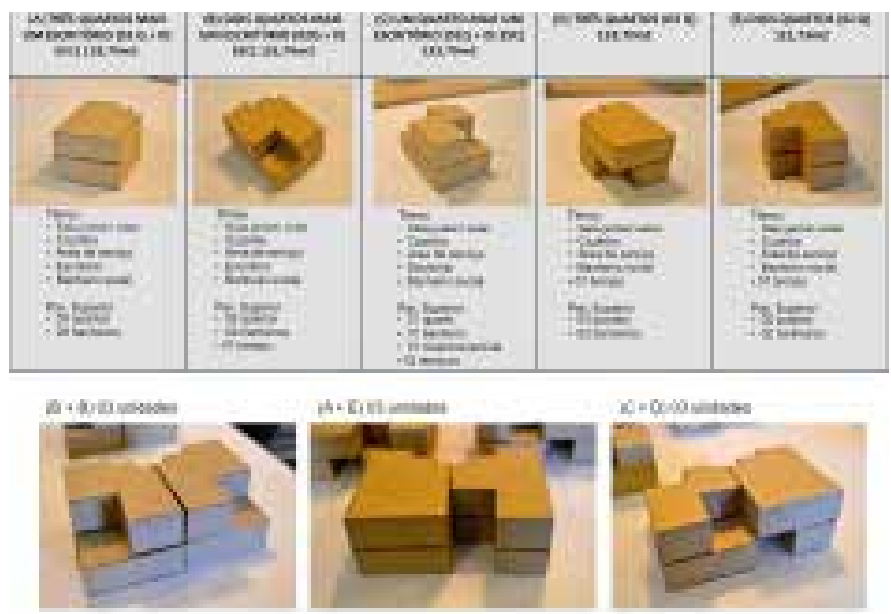

Fonte: CALDAS, 2014.

Figura 05: Grupos geminados - sombreamento lateral e fachadas protegidas e permeáveis

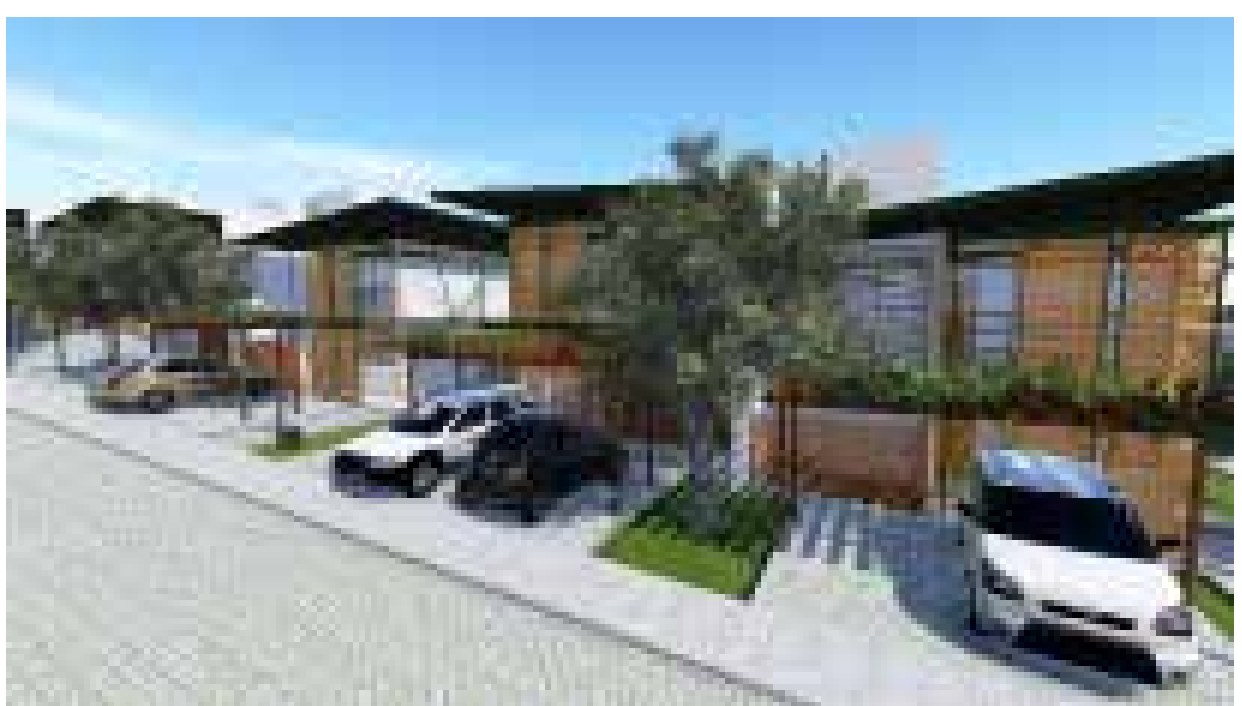

Fonte: CALDAS, 2014. 


\title{
UM LUGAR ONDE OS ESPAGGOS ENSINAM: ANTEPROJETO ARQUTTETONNICO DE UMA ESCOLA INFANTILE FUNDAMENTALI EM PARNAMIRIM/RN
}

\section{CIRÍACO, CÉSAR HENRIQUE DE OLIVEIRA}

\author{
Arquiteto, MsC.; Email: cesarhenrique2@hotmail.com \\ Dissertação desenvolvida no Mestrado Profissional em Arquitetura, Projeto e Meio Ambiente da UFRN \\ Orientador: George Ferreira Dantas; Co-orientadora: Gleice Azambuja Elali
}

\section{RESUMO EXPANDIDO}

Com base em uma reflexão sobre a maneira como a arquitetura de edifícios escolares pode transmitir ensinamentos, ao dialogar com o projeto pedagógico e com o meio ambiente, a dissertação apresenta a proposta arquitetônica de uma unidade de ensino infantil e fundamental I, para o município de Parnamirim/RN. A proposta teve como ênfase a arquitetura bioclimática (consideradas as condicionantes climáticas da Zona Bioclimática 08) e a flexibilidade espacial, tomados como alicerces para o desenvolvimento do anteprojeto.

Como modelo pedagógico foi adotado o Reggio Emilia que, entre outros princípios, tem o ambiente como terceiro educador, entendendo que ele é passivo de transformações e deve despertar nos alunos a curiosidade, a interação e a busca pelo conhecimento. Para tanto, são características a buscar em projetos reggianos: transparência, relação do edifício com a identidade local, diálogo entre interior e o exterior, iluminação natural e presença de ambientes de ateliê.

Além de revisão bibliográfica relativa a assuntos ligados aos temas escola, flexibilidade e arquitetura bioclimática, e de estudos de referência em projetos de edifícios escolares, o processo de desenvolvimento da proposta é descrito detalhadamente em termos de análise das condicionantes projetuais, programação arquitetônica, definição do conceito do projeto e estudos preliminares. Tais elementos foram trabalhados na proposta cujas principais metas foram: possibilidade de diversidade de arranjos em sala de aula; utilização de áreas externas para usos diversos; uso de ventilação e iluminação natural na maior parte do dia em pelo menos $80 \%$ do período letivo de aula.

A escola está implantada em terreno de $6.141,99 \mathrm{~m}^{2}$ localizado no bairro Liberdade, um dos mais carentes do município, e foi direcionada a um público alvo de crianças na faixa etária de 4 a 10 anos, atendendo 160 alunos por turno. Ela conta com 7 salas de aula, todas em pavimento térreo, e tem área total projetada de 1.943,37m² (Figura 1).

O partido adotado contemplou uma implantação de blocos de sala de aula, administração e serviços ao longo da face maior do lote e em torno de um pátio descoberto; a preservação da vegetação arbórea existente no local para ser uma grande área sombreada que protege e abraça o edifício; além da apropriação da esquina para um espaço destinado a praça que faria a transição entre a área pública (rua) e a escola.

Os conceitos que nortearam o anteprojeto foram permeabilidade e ludicidade (Figura 2). Permeabilidade na maneira como os espaços conectam-se proporcionando uma livre circulação; no uso de materiais que possibilitem o aproveitamento da iluminação e ventilação naturais; e na conexão entre o exterior e o interior da edificação, inclusive com a definição de praça de contato com a comunidade (Figura 3). Ludicidade como valor a ser perseguido nos ambientes para crianças, caracterizada no anteprojeto por: espaços destinados a atividades artísticas e brincadeiras (Figura 4); forma dos blocos; uso de cores, texturas e mobiliários.

A fim de verificar a eficiência da edificação quanto ao conforto ambiental foi escolhida a sala de aula (Figura 5) para simulações e avaliações de ventilação natural, sombreamento e iluminação natural por meio de ferramentas computacionais. Os resultados obtidos demonstraram a eficiência das soluções apresentadas: número de trocas de ar dentro da sala de aula duas vezes maior do que o estabelecido pelo MEC; sombreamento acima de 90\% na maioria dos casos; atendimento ao nível de iluminância de 500lux estabelecido pelo MEC. 


\section{FIGURAS}

Figura 1- Vista geral da implantação

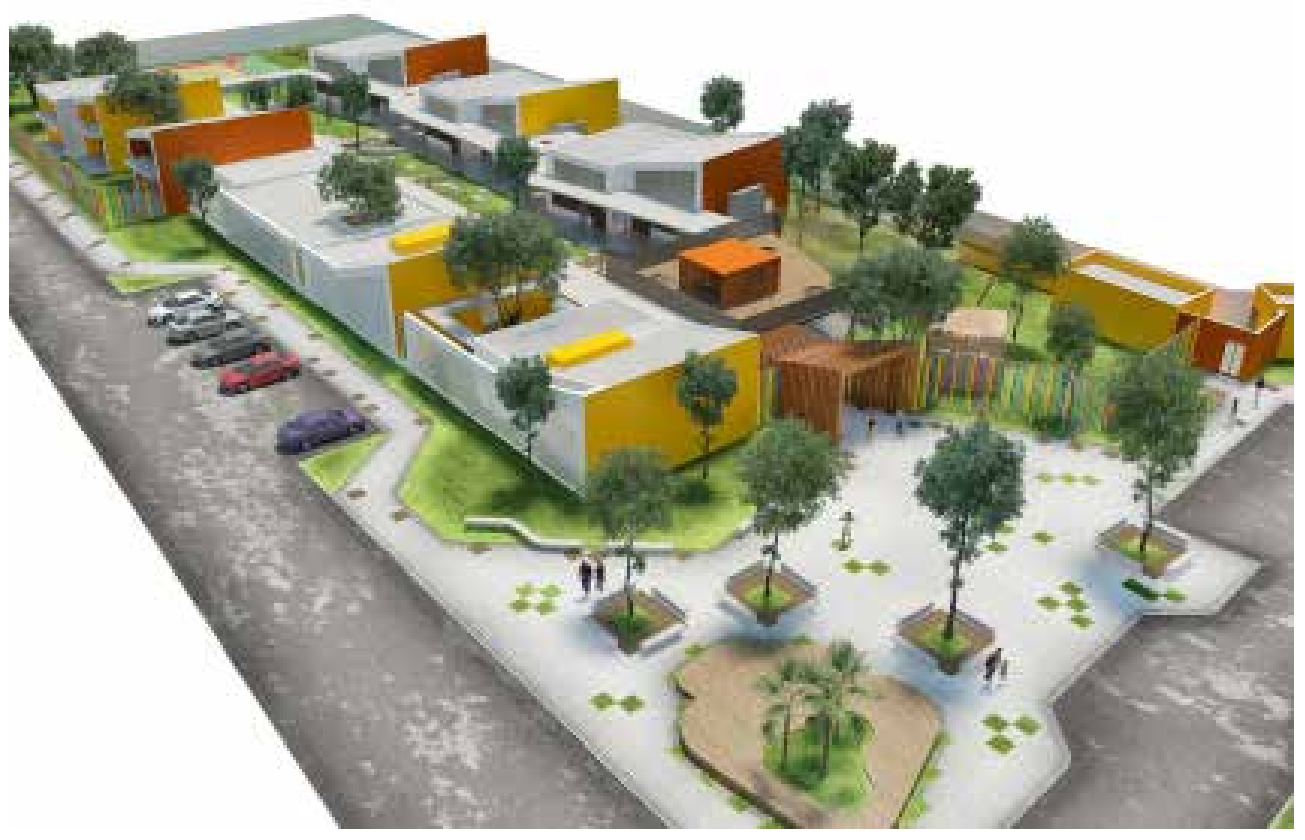

Fonte: CIRÍACO, 2016.

Figura 2- Elementos de projeto

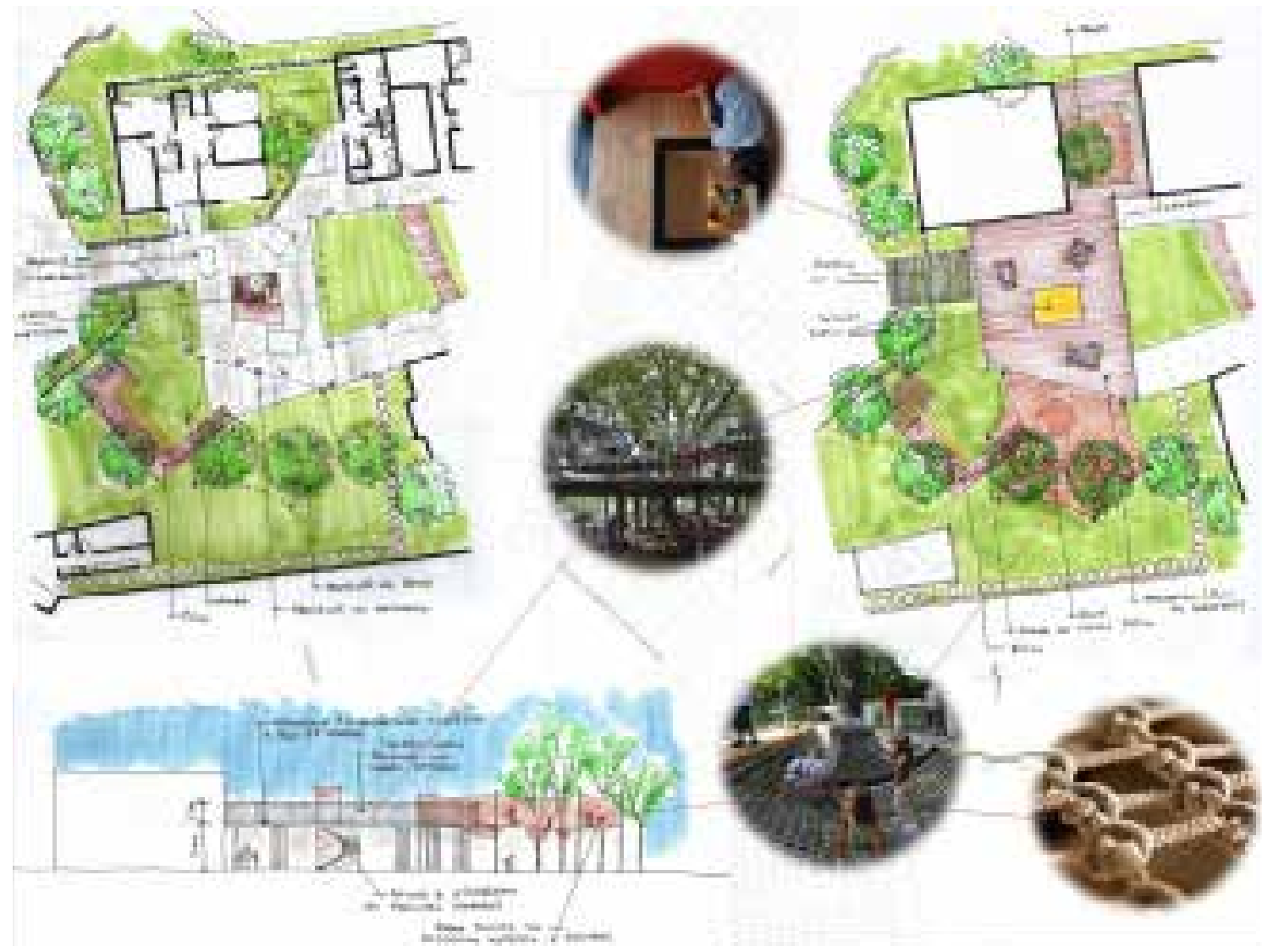

Fonte: CIRÍACO, 2016. 
Figura 3 - Praça na entrada: contato com a comunidade

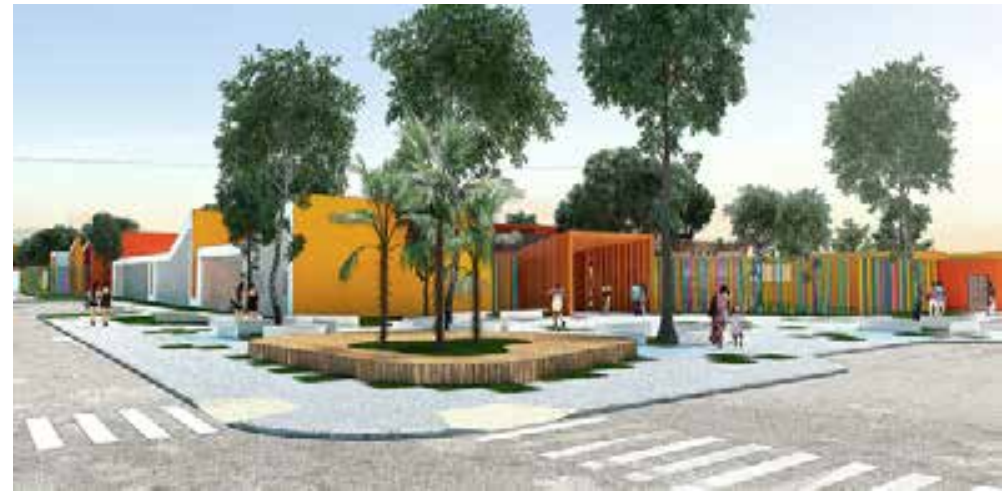

Fonte: CIRÍACO, 2016.

Figura 4 - Espaços internos

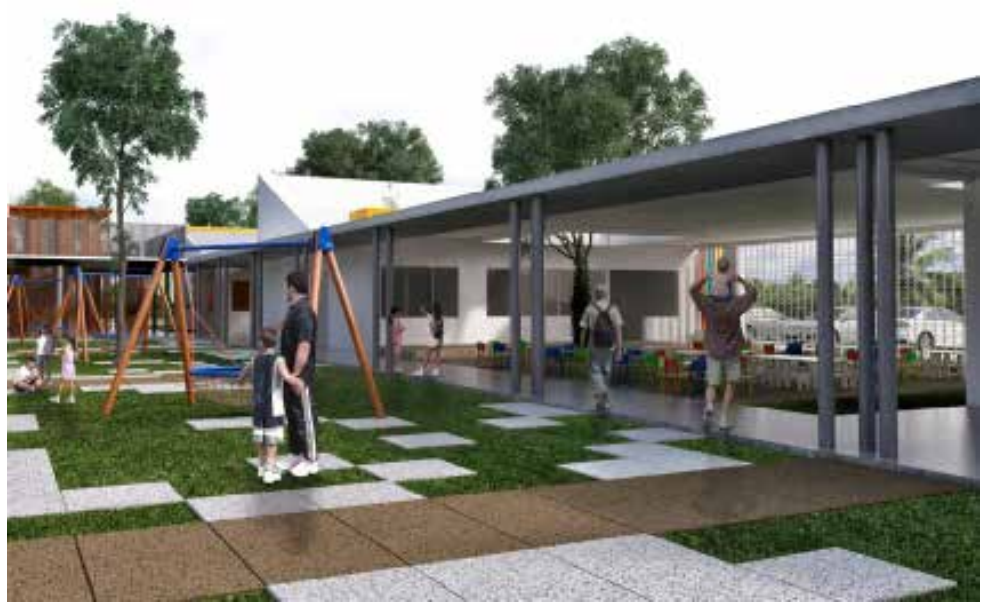

Fonte: CIRÍACO, 2016

Figura 5 - Praça na entrada: contato com a comunidade
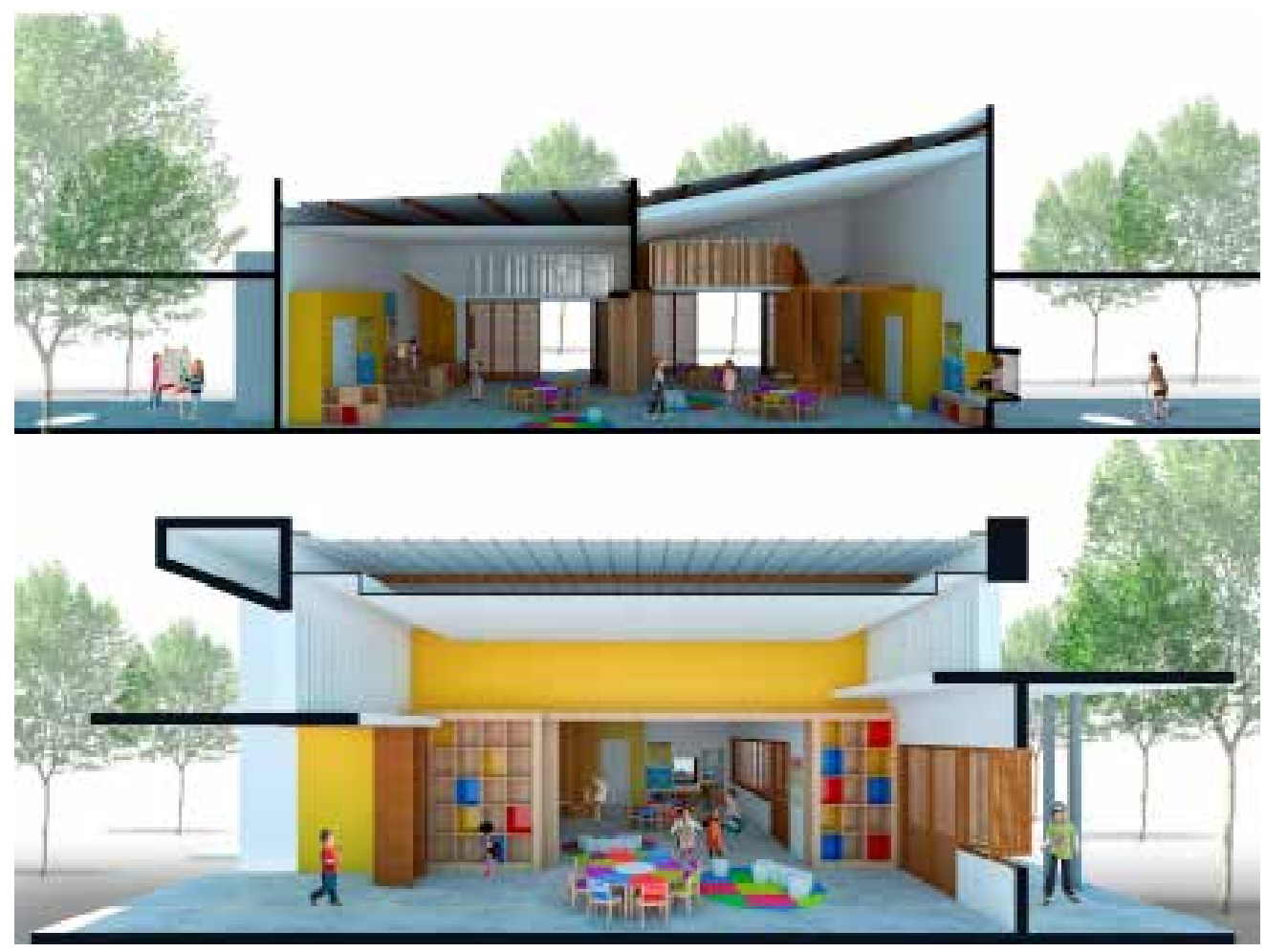

Fonte: CIRÍACO, 2016 


\title{
UM ESPAÇO PARA VIVÊNCIAS AFETIVAS COM A CIDADE DE NATAL
}

\author{
ROCHA V. NETO, FRANCISCO \\ Arquiteto, MsC.; Email: chicorocha00@hotmail.com \\ Dissertação desenvolvida no Mestrado Profissional em Arquitetura, Projeto e Meio Ambiente da UFRN \\ Orientadora: Edna Moura Pinto
}

\section{RESUMO EXPANDIDO}

A pesquisa de mestrado procurou evidenciar e contribuir para a importância da construção de espaços com ênfase na urbanidade, através da criação de um projeto de arquitetura que integrasse e redesenhasse a malha urbana por meio da implantação de um edifício. O trabalho consistiu no desenvolvimento do anteprojeto arquitetônico do Cais da Memória, um complexo arquitetônico para vivências afetivas com o ambiente de Natal, que se dariam por meio da ocupação e deslocamento pelo território da cidade por terra, água e ar, a partir de um edifício de escala e espacialidade urbanas, com funções de centro de atividades culturais e estação intermodal do sistema de transporte público de passageiros. Implantado às margens do rio Potengi, entre o centro antigo tombado, o monumento da Pedra do Rosário e a comunidade AEIS Passo da Pátria, o projeto objetivou a valorização e integração dessas quatro áreas entrincheiradas e de grande valor simbólico e histórico para a cidade.

Para realização do objetivo, o trabalho baseou-se em quase sua totalidade na estrutura curricular e nos conteúdos programáticos das disciplinas cursadas no PPAPMA-Programa de pós-graduação em Arquitetura, Projeto e Meio Ambiente (mestrado profissional). A exceção foi parte do capítulo 2 (referencial teórico), que utilizou trecho da segunda parte do livro Lugares e suas interfaces Intraurbanas. O percurso vivenciado no mestrado foi utilizado como espinha dorsal do processo da pesquisa e do projeto, apresentado na dissertação em 05 capítulos que contemplaram: 1) Introdução, problematização, objetivos e metodologia; 2) Construção de referencial teórico (a partir dos temas abordados nas disciplinas cursadas no PPAPMA) e projetual (edifícios visitados e vivenciados por esse autor), com levantamento e análise desses modelos antecedentes sobre o tema; 3) Estratégias para subsídios à elaboração da proposta arquitetônica por meio de: a) estabelecimento da programação arquitetônica, b) escolha do universo de estudo (terreno de intervenção); c) levantamento e análise dos condicionantes legais e ambientais; d) estudo das variantes climáticas e adoção de soluções em função das estratégias bioclimáticas sugeridas; e) estudos para configuração fenomenológica e da tectônica do objeto (escolhas da espacialidade e dos materiais como elementos para construção de uma narrativa arquitetônica de continuidade do espaço com seu entorno, e técnica e sistema construtivo); f) escolha do conceito do projeto, e 4) Processo criativo de elaboração da arquitetura, com a descrição das matrizes e soluções de desenho e espaços a partir do atendimento aos quatro grandes impedimentos/restrições à ocupação do lugar: a) CBTU - Companhia Brasileira de Trens Urbanos para ocupação da linha férrea, b) Capitania dos portos e legislação ambiental para ocupação das margens do rio, c) SEMURB - Secretaria Municipal de Meio Ambiente e Urbanismo com restrição das leis de uso e ocupação do solo para as AEIS - Área Especial de Interesse Social e Patrimônio Histórico, com restrições para ocupação do entorno da área tombada.

Do ponto de vista da didática arquitetônica, o trabalho aborda a importância em considerar e integrar as características geomorfológicas da malha urbana com seus equipamentos, instalações e soluções construtivas como elementos fundamentais para nortear e engendrar a criação da tectônica e dos espaços no desenho do projeto. O resultado (conforme figuras anexas) é um partido com um corpo principal de altura máxima, escondido à frente dos arrimos da Avenida do Contorno, desimpedindo a visualização da colina histórica e livrando as vias para o deslocamento de caminhões de grande porte que trafegam ao porto, com a cota de piso 0,00 nivelada à linha férrea, livrando o térreo da cota máxima da cheia do rio Potengi a cada 100 anos. O corpo maciço em madeira e metal possui um teto jardim, que é extensão da praça pública da colina à frente e conecta-se a essa, por meio de duas passarelas com equidistância entre si, que determinam a medida padrão da malha sobre a qual se construiu o projeto. O corpo é sustentado por uma estrutura em 
pórticos de madeira e tirantes de aço aparente, que se projetam sobre a linha férrea e o leito do rio, e ao qual anexam-se um ancoradouro de embarcações, um viaduto e uma plataforma, a conectar as partes segregadas da malha urbana (Rio Potengi, Passo da Pátria e Pedra do Rosário). A proposta caracteriza-se ainda pela: a) Integração espacial entre os marcos de interesse urbanístico do local, com a costura e conexão entre as áreas entrincheiradas por soluções de acessibilidade, transparência visual e espacial b) Intermodalidade da rede de sistemas do transporte público coletivo de passageiros, c) Configuração e presença da volumetria e de espaços fenomenológicos e d) Inserção de objeto arquitetônico em local de significância afetiva para a cidade/ comunidade. Dessa maneira, a pesquisa de mestrado contribuiu para o aperfeiçoamento de soluções de arquitetura para complexos e edifícios de atividades culturais com significância para localidades, através de respostas que acolhem e redesenham a malha urbana por meio da implantação de um objeto arquitetônico e estabelecem características que deve possuir um espaço público para permitir uma urbanidade sadia por meio da acessibilidade, do encontro, da sociabilidade e da apropriação de um lugar, usando-as como estratégia de revitalização, renovação e requalificação urbana por meio do desenho e ocupação de um edifício.

NOTA DO EDITOR (*) O conteúdo do artigo e as imagens nele publicadas são de responsabilidade do(s) autor(es).

\section{FIGURAS}

Figura 1 - Implantação do complexo sobre a linha férrea e às margens do rio Potengi, configurando continuidade espacial entre o centro histórico, a Pedra do Rosário e AEIS Passo da Pátria.

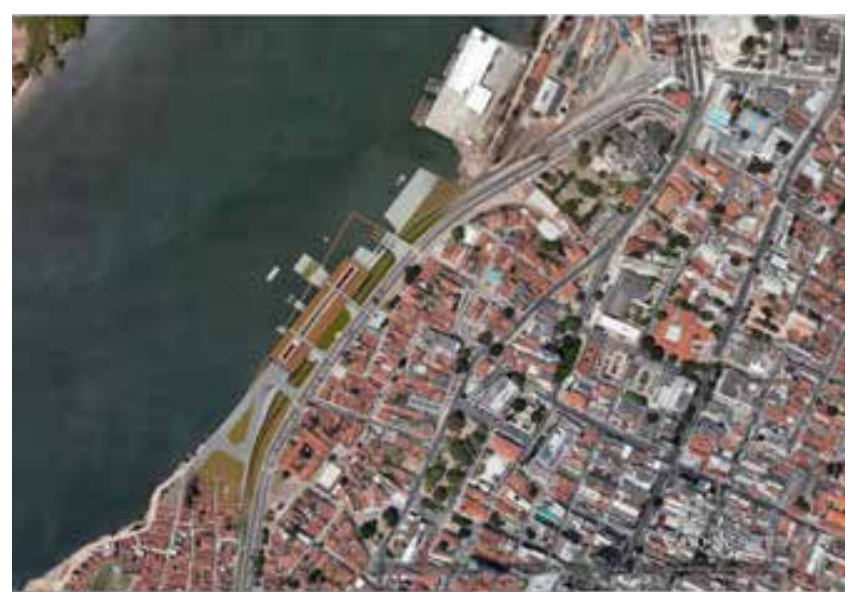

Fonte: ROCHA NETO, 2016.

Figura 3 - Fachadas Nordeste e Noroeste entre a Pedra do Rosário, Centro Histórico e AEIS Passo da Pátria. Destaque para passarelas, escadaria, pier, torre e teto jardim mirante.

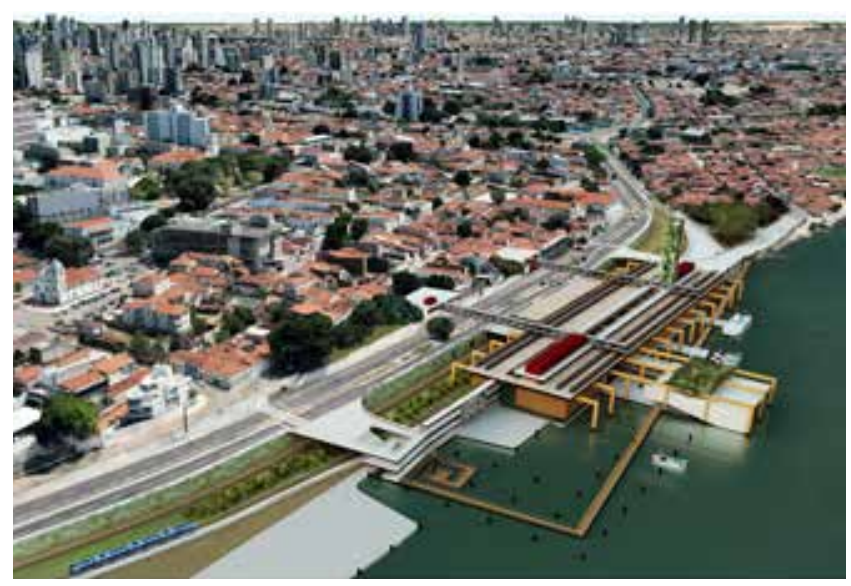

Fonte: ROCHA NETO, 2016.
Figura 2 - Fachadas Noroeste e Sudeste. Destaque para inserção e costura do complexo na malha urbana e intermodalidade por acessibilidade a pé, por trem, autos e embarcações náuticas.

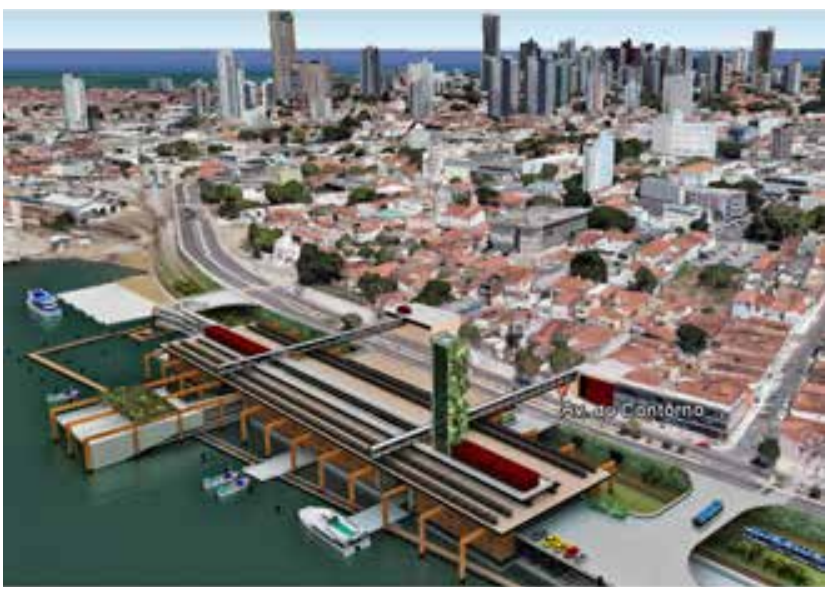

Fonte: ROCHA NETO, 2016.

Figura 4 - Fachadas Sudeste e Sudoeste. Destaque para possibilidade de uso do complexo e deslocamento pelo território por terra, água e ar, a partir do edifício.

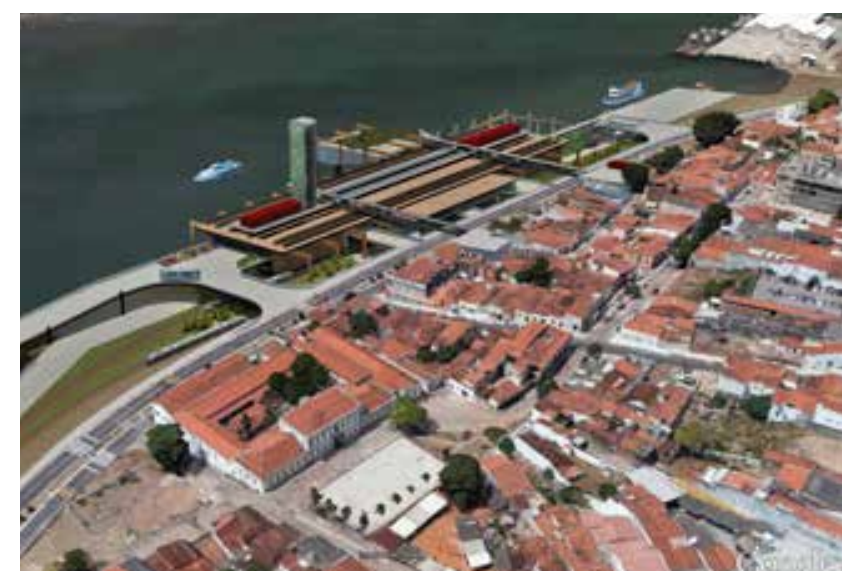

Fonte: ROCHA NETO, 2016. 
Figura 5 - Fachadas Noroeste e Sudoeste, vista do Pier sobre o rio Potengi. Destaque para o sistema estrutural com lajes sustentadas por cabos de aço aparente e atirantado ao pórtico de madeira

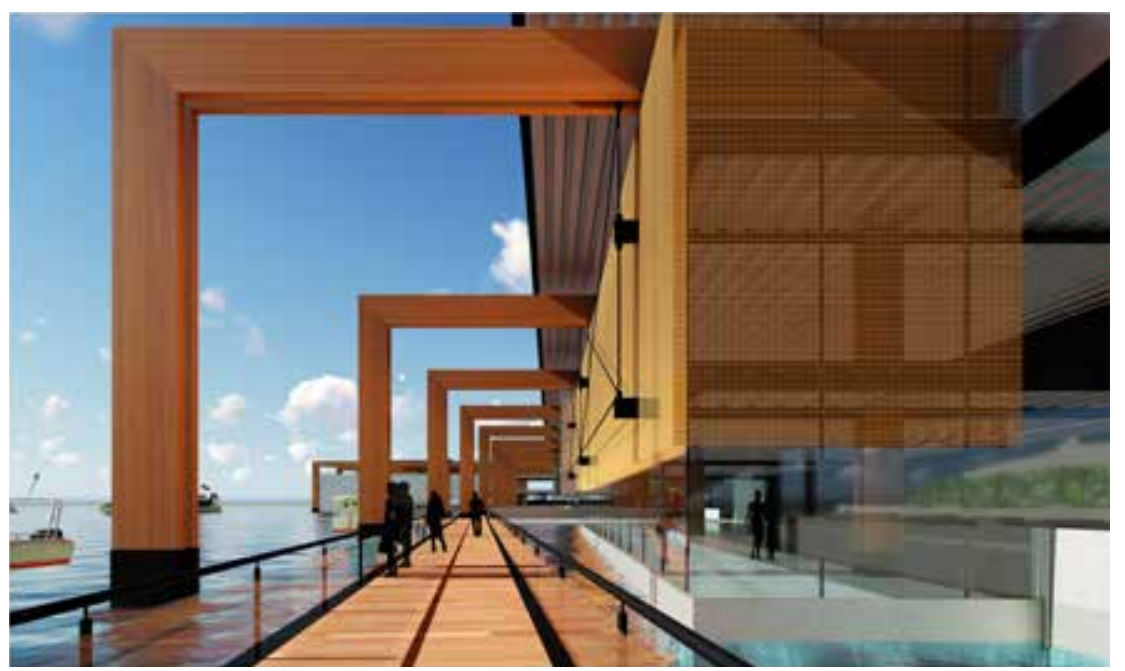

Fonte: ROCHA NETO, 2016.

Figura 6 - Fachada Sudeste e Sudoeste com plataforma do VLT sob a linha férrea. Destaque para o sistema estrutural com cabos de aço aparente e atirantado ao pórtico de madeira

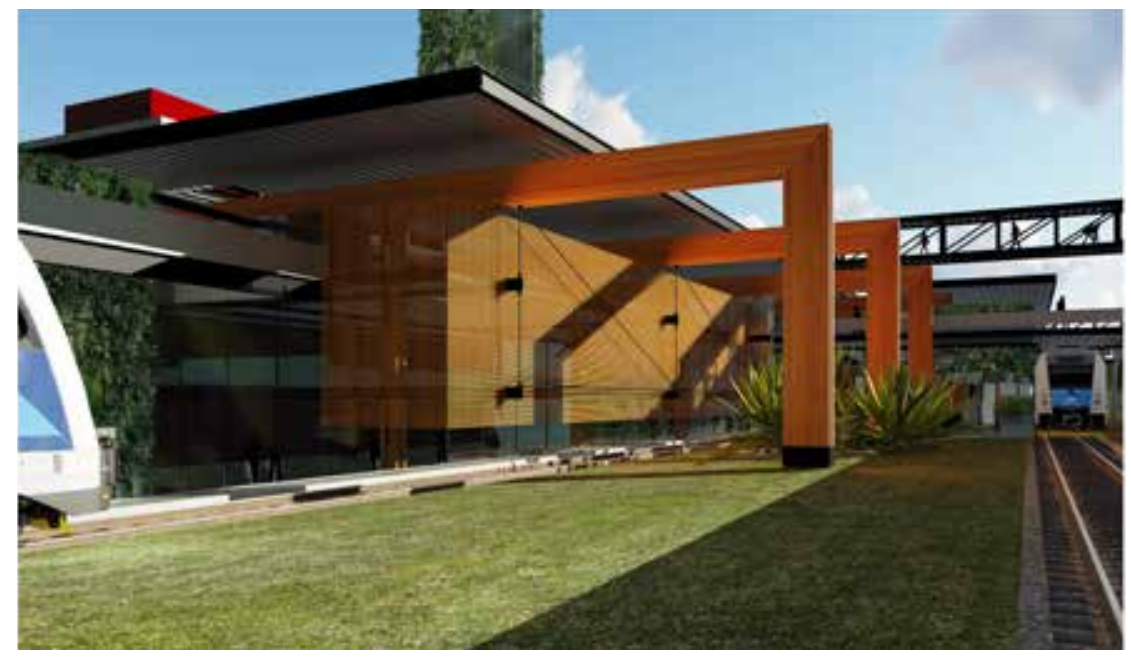

Fonte: ROCHA NETO, 2016.

Figura 7 - Vista área da nova estrutura da Pedra do Rosário.

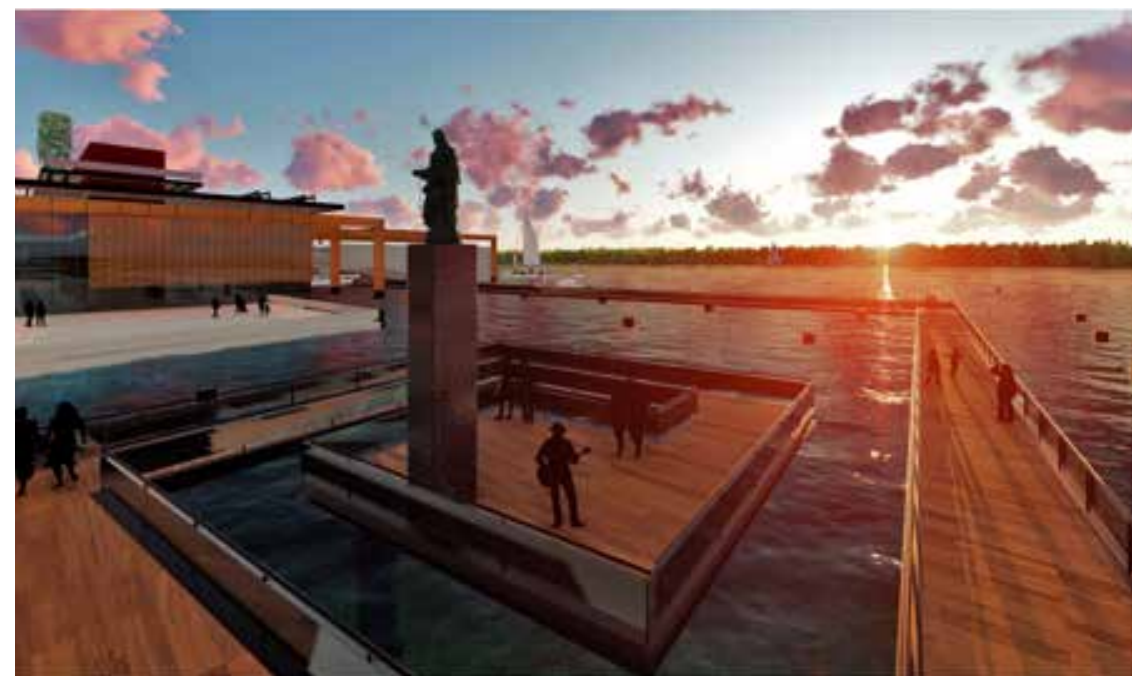

Fonte: ROCHA NETO, 2016. 
Figura 8 - Perspectiva explodida do complexo. Destaque para o engendramento e fluidez do corpo dissecado nas lajes de piso, estrutura, coberta, esquema de circulações e blocos de serviço.

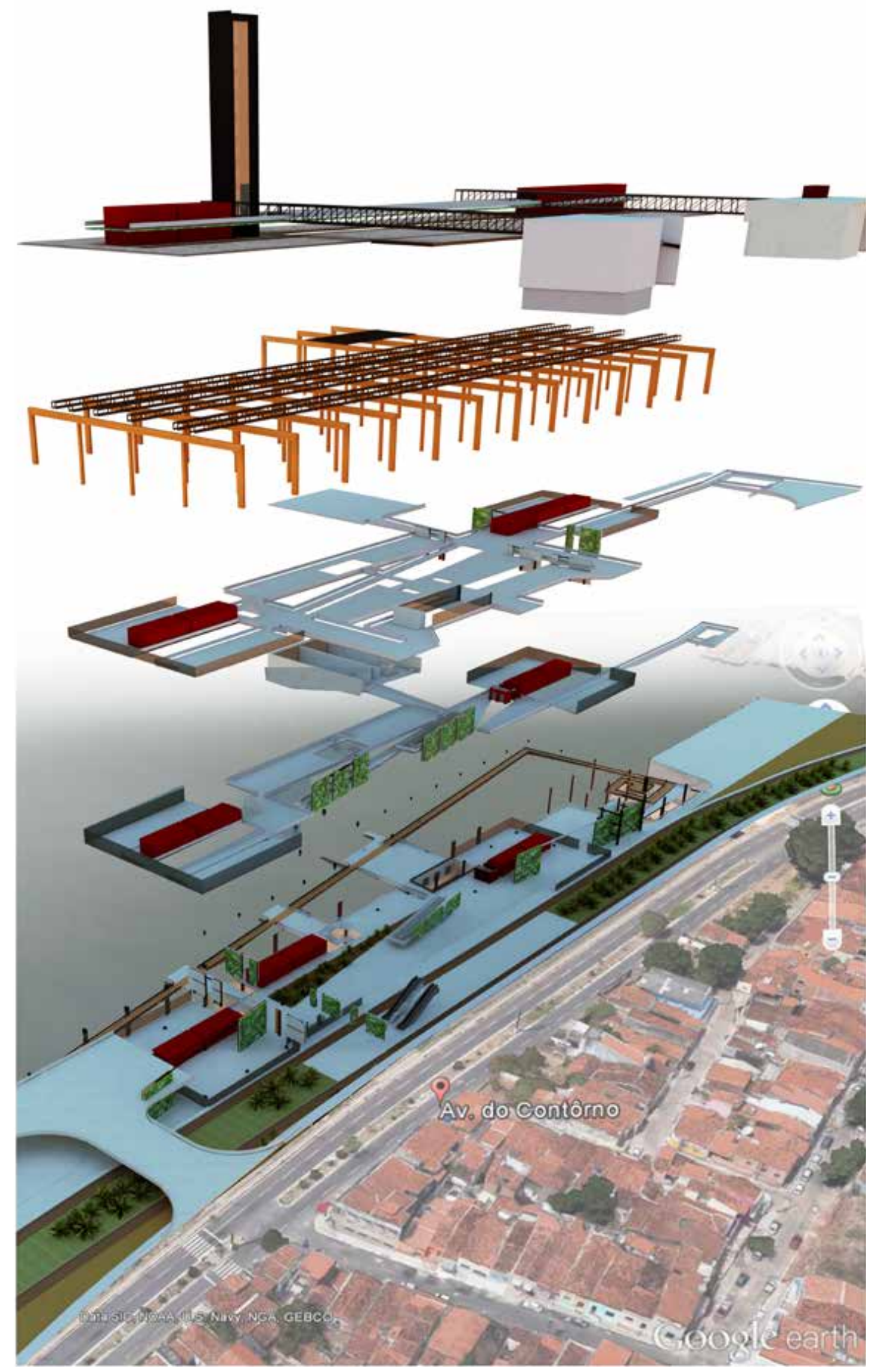

Fonte: ROCHA NETO, 2016. 